UCD CENTRE FOR ECONOMIC RESEARCH

WORKING PAPER SERIES

2010

\title{
Recent Developments in Intergenerational Mobility
}

Sandra E Black, University of Texas at Austin and

Paul J Devereux, University College Dublin

WP10/10

April 2010

\section{UCD SCHOOL OF ECONOMI CS UNI VERSI TY COLLEGE DUBLI N}

BELFI ELD DUBLI N 4 


\title{
Recent Developments in Intergenerational Mobility ${ }^{*}$
}

\author{
by \\ Sandra E. Black \\ Department of Economics \\ University of Texas at Austin, IZA and NBER \\ sblack@austin.utexas.edu \\ Paul J. Devereux \\ School of Economics and Geary Institute \\ University College Dublin, CEPR and IZA \\ devereux@ucd.ie
}

April 2010

* Prepared for the Handbook of Labor Economics. We would like to thank Anders Bjorklund, Dan Hamermesh, Helena Holmlund, Kanika Kapur, Gary Solon, Alexandra Spitz-Oener, and Steve Trejo for helpful comments. Prudence Kwenda provided excellent research assistance. Devereux thanks the Irish Research Council for the Humanities and Social Sciences (IRCHSS) for financial support. This chapter was completed while Black was on leave from the economics department at UCLA. 
Table of Contents

Introduction

1. Intergenerational Correlations of Earnings and Education

1.1 Issues in Estimating the Intergenerational Elasticity of Earnings

- Persistent Transitory Shocks

- Ages of Fathers and Sons

- Lifecycle Bias

- Transition Matrices

1.2 Recent Estimates of the IGE by Country and Over Time

- Estimates for Son Earnings

- Estimates for Daughter Earnings

- Estimates for Family Earnings

- Changes in IGE Over Time

- Why IGE Might Differ across Country and Over Time

1.3 Credit Constraints and the IGE

1.4 Intergenerational Transmission of Education

- Estimation Issues

- Estimates by Country and Over Time

2. Identifying the Causal Effects of Parental Education and Earnings

2.1 Method 1: Sibling and Neighborhood Correlations

- Sibling Correlations

- Neighborhood Correlations

2.2 Method 2: Structural Analysis of Different Types of Siblings

2.3 Method 3: Decompositions of Intergenerational Persistence

2.4 Method 4: Sibling and Twin Differences

2.5 Method 5: Regression Analysis Using Adoptees

- Bivariate Regression Approach

- Multivariate Regression Approach

- Using Information on Biological and Adoptive Parents

2.6 Method 6: Natural Experiments/Instrumental Variables Estimates

- Income

- Education

- Parental Education and Infant Health

- Limitations of IV Approach

2.7 Reconciling Findings of Twins/Adoptees/IV Literatures

3. Other Family Background Characteristics

$3.1 \mathrm{IQ} /$ Ability

3.2 Jobs and Occupations

3.3 Welfare Receipt

3.4 Health

3.5 Attitudes and Social Behavior

3.6 Consumption and Wealth

4. Conclusions

References 


\section{Introduction}

Economists and social scientists have long been interested in intergenerational mobility, and documenting the persistence between parents and children's outcomes has been an active area of research. However, since Gary Solon's 1999 Chapter in the Handbook of Labor Economics, the literature has taken an interesting turn. In addition to focusing on obtaining precise estimates of correlations and elasticities, the literature has placed increased emphasis on the causal mechanisms that underlie this relationship.

This chapter describes the developments in the intergenerational transmission literature since the 1999 Handbook Chapter. While there have been some important contributions in terms of measurement of elasticities and correlations, we will focus primarily on advances in our understanding of the forces driving the relationship and less on the precision of the correlations themselves. Also, since intergenerational research has mostly used data from Europe and North America, our summary is largely restricted to these countries.

Which brings us to the motivation for all of this research: What is the "optimal" amount of intergenerational mobility? Many people favor equality of opportunity as an underlying goal of society - the idea that poor children should have the same opportunities for success as rich children. Those who work hard should be able to succeed, regardless of family background. However, zero intergenerational correlation is not necessarily the optimum.

In order to determine a socially optimal level of mobility, it is important to understand the underlying causes or determinants of the intergenerational correlation in earnings or education. As noted in Solon (2004), children of wealthy parents earn higher 
incomes in part because they invest more in human capital and have more education. As a result, observing zero intergenerational correlation would suggest no return to human capital investment, and it would be a strange market economy if higher human capital was not rewarded with higher earnings. This does, however, highlight the importance of understanding the mechanisms underlying the observed intergenerational correlations; if they are in fact due to differential human capital investment, this suggests a role for public provision or financing of education to equalize opportunities.

In a similar manner, there may be genetic differences in ability that are transmitted from parent to child and that lead to intergenerational persistence in income or education. To the extent that this is the underlying cause of the intergenerational correlation in income or education, it may suggest a more limited role for policy. ${ }^{1}$

Overall, differences in ability and human capital will tend to lead to an intergenerational correlation of greater than zero in any well-functioning market economy. Policies that compel employers to favor less qualified applicants in terms of employment or pay may reduce the intergenerational correlation but at a high cost to society in terms of efficiency and incentives for human capital accumulation. As such, they are not necessarily desirable. On the other hand, the use of connections to get jobs by the children of the wealthy when other candidates are better qualified is manifestly inefficient, and the component of the intergenerational correlation due to nepotism would be considered by most to be best eradicated.

\footnotetext{
${ }^{1}$ Of course, the policy implications of the genetic/environmental distinction are not so clear cut, as genetic differences can be influenced by policy - a famous example is that genetic deficiencies in eye sight can be ameliorated by the provision of spectacles (Goldberger, 1979). Similarly, minimum wages can increase the earnings of low-skill workers.
} 
The structure of the chapter is as follows: In the first section, we describe recent advances in the methodology for estimating intergenerational earnings and education persistence and provide an overview of the empirical findings. As noted above, throughout the handbook chapter, we focus explicitly on more recent advances in the literature, particularly since the publication of Solon's 1999 handbook chapter. Section 2 describes and critically evaluates the main methods that have been used to identify causal effects of parental earnings and education. In section 3, we move away from earnings and education and discuss the literature on the intergenerational correlations of other family background factors. Finally, section 4 concludes.

\section{Section 1: Intergenerational Correlations of Earnings and Education}

Perhaps the most basic empirical relationship in this literature relates the earnings of parents to that of their children. Given that this equation is usually estimated using log earnings for both parents and children, the resultant estimate is the intergenerational earnings elasticity. We will consider the benchmark regression:

$$
\log \left(Y_{1}\right)=\alpha+\beta \log \left(Y_{0}\right)+\varepsilon
$$

Using lowercase for logs, and taking deviations from population means to remove the intercept, we can write this as

$$
y_{1}=\beta y_{0}+e
$$

Here the subscript 1 refers to the child, 0 refers to the parent, and $y$ is a measure of permanent earnings. The parameter $\beta$ is the intergenerational elasticity (henceforth, IGE) and $(1-\beta)$ is a measure of intergenerational mobility. 
The intergenerational correlation $(\rho)$ is an alternative to the elasticity that has also been widely used in the literature. The correlation between the log earnings of parent and child equals the elasticity provided that the standard deviation of log earnings is the same for both generations. To see this, note that the intergenerational correlation

$$
\rho=\left(\sigma_{1} / \sigma_{0}\right) \beta
$$

where $\sigma$ is the standard deviation of log earnings. The correlation therefore factors out the cross-sectional dispersion of log earnings in the two generations. In contrast, the elasticity can be higher in one society than in another simply because the variance of log earnings in the child's generation is higher in that society. This is related to the fact that the correlation is bounded between 0 and 1 while the elasticity, in principle, could be greater than one and would, for example, equal 2 if people from families who were $10 \%$ apart in generation 0 , were $20 \%$ apart in generation 1 . We don't believe one measure should be seen as dominating the other but it is important to be aware of their differing properties, particularly when making comparisons across time or place. One practical advantage of the elasticity is that, unlike the correlation, it is not biased by classical measurement error in $y_{1}$ and so is often easier to estimate with real-world data.

\subsection{Issues in Estimating the Intergenerational Elasticity of Earnings}

There are a number of recent developments in terms of the estimation of intergenerational income elasticities. Once again, we consider the benchmark regression in equation (2):

$$
y_{1}=\beta y_{0}+\varepsilon
$$


The important issue for measurement is that $y$ should be a measure of permanent earnings. The data requirements are obviously challenging as few datasets have information that allows the calculation of lifetime earnings for both fathers and sons. For now, we will consider the regression of son's permanent earnings on father's permanent earnings. ${ }^{2}$ As is well known, the estimate of $\beta$ will be biased if father's permanent earnings are measured with error, but not if son's earnings are subject to classical measurement error. ${ }^{3}$ Early estimates of the intergenerational elasticity tended to use earnings in one year for both fathers and sons; however, pioneering work by Solon (1992) and Zimmerman (1992) demonstrated that sizeable biases arose from this approach and improved measurement of father's earnings by averaging over 4 or 5 years. Recent research has focused on obtaining better estimates of permanent earnings by (1) averaging over even more years of data to allow for persistent transitory shocks and (2) paying careful attention to the ages of both fathers and sons at the time earnings are measured.

\section{Persistent Transitory Shocks}

Assume $y_{0 a}=y_{0}+v_{a}$ where $a$ is the age of the father when earnings are measured and $v$ (assumed uncorrelated with $y_{0}$ ) is the deviation between measured earnings at age $a$ and permanent earnings. If $v$ is a purely transitory shock, the

\footnotetext{
${ }^{2}$ The literature has mostly focused on sons so, in this section, we will report only on father/son correlations and elasticities. We describe results for both sons and daughters in section 1.2.

${ }^{3}$ We use the term measurement error to describe deviations between permanent earnings and whatever measure of earnings is used to proxy for it. This remains an issue even if annual earnings are reported accurately.
} 
attenuation factor in the intergenerational elasticity when one year of data is used equals $\frac{\operatorname{var}\left(y_{0}\right)}{\operatorname{var}\left(y_{0}\right)+\operatorname{var}(v)}$, i.e. $p \lim \hat{\beta}=\left(\frac{\operatorname{var}\left(y_{0}\right)}{\operatorname{var}\left(y_{0}\right)+\operatorname{var}(v)}\right) \beta$.

If we instead average earnings over $\mathrm{T}$ years for each father, the attenuation factor becomes $\frac{\operatorname{var}\left(y_{0}\right)}{\operatorname{var}\left(y_{0}\right)+\operatorname{var}(v) / T}$ and so rapidly declines with T. Solon (1992) demonstrates the impact of allowing first-order persistence in $v$ using MA(1) and $\mathrm{AR}(1)$ processes and Mazumder (2005) emphasizes the importance of such persistence using an AR(1) process. Suppose $v_{a}=\delta v_{a-1}+\omega_{a}$ and $\omega_{a}$ is iid. The attenuation factor now becomes $\frac{\operatorname{var}\left(y_{0}\right)}{\operatorname{var}\left(y_{0}\right)+\gamma \operatorname{var}(v) / T}$ where $\gamma=1+2 \delta\left(\frac{T-\left(1-\delta^{T}\right) /(1-\delta)}{T(1-\delta)}\right)$.

Clearly if $\delta>0$, the attenuation bias is larger than in the purely transitory case for any value of T. Mazumder (2005) illustrates this point using simulations for different values of $\delta$ and T and benchmark values for the variances of $y_{0}$ and $v$. He finds that, if $\delta=.5$, the attenuation factor is .69 when earnings are averaged over 5 years; this contrasts to an attenuation factor of .83 in the same circumstances with $\delta=0$. He suggests that intergenerational elasticity estimates from the U.S. of about .4 using 5-year averages should be scaled up to about $.4 / .69$, close to .6. Also, the simulations show that averaging over 20 to 30 years may be necessary to obtain attenuation factors that are about .9 or higher.

Mazumder (2005) also uses the 1984 SIPP data matched to the Social Security Administration's Summary Earnings Records (SER) to provide empirical estimates in which $\mathrm{T}$ is allowed to vary up to 16 years. He finds that the IGE estimate rises from about .25 when $\mathrm{T}=2$, to .45 when $\mathrm{T}=7$, and up to .61 when $\mathrm{T}=16$. Overall, these estimates 
suggest that, at least in the U.S., a high value of T is required in order to accurately

estimate the IGE. ${ }^{4}$

\section{Ages of Fathers and Sons}

To get a sense of how the ages of father and son matter, consider the following simple model based on Haider and Solon (2006). ${ }^{5}$ Assume earnings for fathers and sons are measured at a particular age, $a .^{6}$

$$
\begin{aligned}
& y_{0 a}=\mu_{a} y_{0}+v \\
& y_{1 a}=\lambda_{a} y_{1}+u
\end{aligned}
$$

This parameterization of the error allows for the fact that one-period earnings may be a better proxy for life-time earnings at some ages than at others. Assuming that the error terms are uncorrelated with each other and with lifetime earnings (which may be a strong assumption as fathers and sons may have similar career paths), the probability limit of the estimate of the intergenerational elasticity is

$$
\beta\left[\frac{\lambda_{a} \mu_{a} \operatorname{var}\left(y_{0}\right)}{\mu_{a}^{2} \operatorname{var}\left(y_{0}\right)+\operatorname{var}(v)}\right]=\beta \lambda_{a} \theta_{a}
$$

where $\theta_{a}=\left[\frac{\mu_{a} \operatorname{var}\left(y_{0}\right)}{\mu_{a}^{2} \operatorname{var}\left(y_{0}\right)+\operatorname{var}(v)}\right]$.

This simple model has several implications. First, if $\lambda_{a}=\mu_{a}=1$, then this is the standard errors-in-variables model and the intergenerational elasticity suffers from attenuation

\footnotetext{
${ }^{4}$ Using Norwegian register data, Nilsen et al. (2008) find that averaging extra years of father's earnings has smaller effects on the estimated IGE. These smaller effects may be the result of lower transitory variation in earnings in Norway compared to the U.S., and they suggest that Mazumder's findings may be U.S.specific.

${ }^{5}$ For earlier work on this topic, see Jenkins (1987).

${ }^{6}$ Note that the analysis does not rely on the age of fathers and sons being the same.
} 
bias. Second, even when $\lambda_{a}=\mu_{a}=1$, the extent of the attenuation bias may depend on father's age, as var( $v)$ may itself depend on age. ${ }^{7}$ Baker and Solon (2003) and Mazumder (2005) provide evidence that $\operatorname{var}(v)$ varies over the life-cycle and is at its minimum at around age 40 . Third, $\theta_{a}$ can exceed 1 and is increasingly likely to as $\mu_{a}$ becomes smaller. Therefore, in general the bias to the intergenerational elasticity need not be an attenuation bias. Fourth, measurement error in the dependent variable $\left(y_{1}\right)$ causes bias so long as $\mu_{a}$ does not equal one, and the size of the bias potentially depends on the age of the son.

\section{Lifecycle Bias}

Lifecycle bias occurs when $\lambda_{a}$ or $\mu_{a}$ take different values at different ages. This is an important issue in practice, as data limitations make it likely that fathers' earnings are measured relatively late in the lifecycle while sons' earnings are typically measured at quite young ages. With complete information on earnings over a full career, it is possible to estimate $\lambda_{a}$ and $\theta_{a}$ at each age.

Haider and Solon (2006) show that $\lambda_{a}$ can be estimated by simply regressing log earnings at age $a$ on the log of the present value of lifetime earnings (which can be calculated if earnings over the entire career are observed). Similarly, $\theta_{a}$ can be estimated as the slope coefficient in the reverse regression of the log of the present value of earnings on the $\log$ of earnings at age $a$. They use social security earnings of persons

\footnotetext{
${ }^{7}$ In the literature, this is not referred to as life-cycle bias; this phrase is reserved for the case where $\lambda_{a}$ or $\mu_{a}$ take different values at different ages.
} 
sampled in the U.S. Health and Retirement Survey (HRS) who agreed to allow access to their earnings histories. The analysis uses earnings from 1951 to 1991 and so covers most of the careers of the 821 men studied. Because the SSA earnings data are censored at the taxable limit, they use a multi-step procedure in estimation and require distributional assumptions. Bohlmark and Lindquist (2006) use Swedish register data to carry out a similar exercise to that of Haider and Solon. Because their earnings data are not censored, they estimate $\lambda_{a}$ and $\theta_{a}$ using the simple regressions described above.

Both papers come to quite similar conclusions: Estimates of $\lambda_{a}$ are low when men are in their twenties (as low as .2 in the U.S. before age 25). The main reason for this is that men who will have high lifetime earnings typically have faster earnings growth and, so, the early-career earnings gap between low and high lifetime earners tends to underestimate the gap in lifetime earnings. Estimates of $\lambda_{a}$ rise to be close to 1 once men reach their thirties and remain high until their late forties. However, by the late fifties, estimates of $\lambda_{a}$ have declined to about .6. Remember that $\lambda_{a}$ represents the attenuation bias that arises because the son's earnings at age $a$ may not be representative of his lifetime earnings. These estimates suggest that there could be large attenuation biases if earnings of sons aged younger than 30 are included in the analysis.

The estimates of $\theta_{a}$ are also similar in the two studies: the estimate starts at about .2 at age 20 and rises to about $.6-.7$ by age 30 . It stays about that value until the late $40 \mathrm{~s}$ and then declines slowly to about $.4-.5$ in the late 50 s. Given that $\theta_{a}$ represents the bias component that results from mis-measurement of father's earnings, we see that, as with sons, it is optimal to measure earnings in the middle of the life cycle. However, even 
when earnings are measured then, the attenuation factor still rises to only about .7 and so there remains significant attenuation bias. ${ }^{8}$

Consistent with the analyses by Haider and Solon (2006) and Bohlmark and Lindquist (2006), Grawe (2006) provides two distinct sources of evidence of life-cycle bias. First, he uses estimates from 20 studies that use a variety of datasets from a number of different countries and shows that there is a negative correlation between age of father at measurement and size of the estimated IGE. Importantly, he finds that father's age at measurement accounts for $20 \%$ of the variance of estimates across the studies. Second, he uses four different datasets (the National Longitudinal Survey, PSID, German Socieconomic Panel (GSOEP), and the Canadian Intergenerational Income Data (IID)) to estimate the IGE while varying the father's age at measurement. Once again, in each dataset, he finds that the estimated IGE tends to fall as father's age increases. Finally, building on earlier work by Reville (1995), he shows that, for any given father's age, the IGE tends to increase as son's age increases.

Most recently, Nilsen et al. (2008) use Norwegian register data to investigate lifecycle bias. Consistent with earlier work, they find that estimated IGEs in father-son regressions decrease by about $1.1 \%$ for each extra year of father's age. These results are interesting as they show that, despite the large differences between the U.S. and Norwegian labor markets, lifecycle bias is a problem of similar magnitude in each.

\footnotetext{
${ }^{8}$ Brenner (2010) examines life-cycle bias using German data and finds estimates for men that are similar to those of Bohlmark and Lindquist (2006).
} 


\section{Transition Matrices}

While much of the literature has focused on estimating the IGE, this summary measure may conceal interesting detail about intergenerational mobility at different points of the joint distribution of parental and child earnings. An alternative strategy is to study mobility matrices and examine the quantile of the child's earnings conditional on the parent's earnings quantile. In addition to providing greater information across the distribution, transition matrices allow one to compare mobility rates of population subgroups across the full earnings distribution rather than just across the earnings distribution for that group. This is impossible with IGE estimation, as splitting the sample by group shows the degree of regression to the subgroup mean not the mean of the whole population.

In practice, researchers often group quantiles. For example, Jantti et al. (2006) split the earnings distributions into quintiles and study mobility across quintiles. Bhattacharya and Mazumder (2008) criticize this standard transition matrices approach for relying on arbitrary discretizations of the distribution (for example, quintiles or quartiles). They propose a new measure of upward mobility - the probability that a son's percentile rank in the earnings distribution of sons exceeds the father's percentile rank in the earnings distribution of fathers. In effect, this implies more weight is placed on small moves, as mobility is noted even if it does not involve the son's quintile (or other discrete measure) being different from the quintile of the father. ${ }^{9}$ Using data from the National Longitudinal Survey of Youth (NLSY), they show that the distinction can matter in practice as the degree of upward mobility of blacks is found to more similar to that of

\footnotetext{
${ }^{9}$ This method also relies on an arguably arbitrary discretization; for a parent in the $20^{\text {th }}$ percentile, a child who moves to the $21^{\text {st }}$ percentile is counted the same as a child who moves to the $95^{\text {th }}$ percentile.
} 
whites when the new measure is used. This highlights the fact that results can vary based on the exact metric used and suggests the value of showing the robustness of estimates to different approaches.

The same issues with imperfect measures of lifetime earnings that arise in estimating the IGE manifest themselves when using mobility approaches. As in the IGE literature, researchers have tended to deal with this by averaging earnings over several years. ${ }^{10}$ O’Neill et al. (2007) directly study the effect of measurement error on transition matrices. They allow for measurement error in both fathers' and sons' earnings and carry out simulations that vary both the variance of the measurement error and the correlation of the error between father. They find that classical measurement error in sons' earnings leads to an overestimate of mobility, with the largest bias in the bottom tail. Interestingly, when both fathers' and sons' earnings are measured with error, the impact depends on the correlation between the measurement errors. With low correlation, the measurement error leads to an overstatement of mobility; high correlations can lead to an understatement. As a result, they caution that measured mobility differences across countries or across the earnings distribution may result from data measurement issues rather than true differences.

\subsection{Recent Estimates of the IGE by Country and Over Time}

By now, there is a large set of estimates of intergenerational mobility from a range of different countries. The availability of large register-based samples has led to a particularly credible set of estimates for Nordic countries that have generally confirmed a

\footnotetext{
${ }^{10}$ For example, Bhattacharya and Mazumder (2008) average sons' earnings over 3 years and fathers' earnings over 4 years.
} 
higher level of mobility than in the U.S. and U.K. However, as described below, careful study of nonlinearities has shown that these differences are not uniform across the earnings distribution.

Given the large number of studies and the fact that estimation methods, variable definitions, and sample selection rules differ widely, we begin by describing results from Jantti et al. (2006) who estimate elasticities and correlations for 6 countries in a comparable fashion. ${ }^{11}$ They use the National Longitudinal Survey of Youth (NLSY) for the U.S., the National Child Development Study (NCDS) for the U.K., and register data for the Nordic countries. To minimize lifecycle bias, they use fathers aged about 45 and sons and daughters aged between 30 and 42 . Because they need to use a similar approach across all countries, they use only one year of earnings data for fathers. As such, these estimates should not be considered as definitive for any particular country; they are useful because they allow a comparison of the relative magnitude of the IGE across countries when similar data and sampling rules are used.

\section{Estimates for Son Earnings}

The top panel of Table 1 provides a summary of IGE estimates and estimated correlations for sons by country (Denmark, Finland, Norway, Sweden, the U.K., and the U.S.) from Jantti et al. (2006). ${ }^{12}$ Both the elasticities and correlations suggest an ordering with the lowest persistence in the Nordic countries, higher persistence in the UK, and the highest persistence in the US. These findings are generally consistent with others in the

\footnotetext{
${ }^{11}$ In the last decade there have been several papers that survey international IGE estimates at length. These include Bjorklund and Jantti (2009), Blanden (2009), Corak (2006), Grawe (2004), and Solon (2002).

${ }^{12}$ The differences between the elasticities and correlations reflect differences in the variances of earnings in the fathers' and sons' generations. For example, the elasticity is higher than the correlation for the US due to the increase in earnings inequality in recent decades.
} 
literature. Based on Table 1 and Mazumder (2005), a reasonable guess is an IGE in the U.S. of about .5 to .6. A reasonable guess for the U.K. is about .3 ((see also Nicoletti and Ermisch (2007), Blanden et al. (2004)). Elasticities for the Nordic countries are almost always found to be lower than.$^{13}$

Jantti et al. (2006) also use transition matrices to estimate mobility by quintile in these countries. They find that more than $40 \%$ of sons in the U.S. who are born to fathers in the lowest quintile are in the lowest quintile themselves. Mobility from the lowest quintile is found to be much higher in Norway and Denmark. Interestingly, they find that the much larger estimated IGE in the U.S. and U.K. compared to the Nordic countries is almost entirely due to differences in the tails. In addition to much higher mobility from the bottom quintile in the Nordic countries, there is much higher mobility from the top quintile in these countries as well. On the other hand, mobility between the middle three quintiles is fairly similar across all countries. ${ }^{14}$

Bratsberg et al. (2007) use data from the U.S., U.K, Denmark, Finland, and Norway to test for nonlinearities in the IGE. They show that while the IGE is close to linear in father's income in the U.S. and U.K., the pattern is convex in the three Nordic countries. ${ }^{15}$ For example, in Denmark, the IGE is .06 at the $10^{\text {th }}$ percentile but .31 at the $90^{\text {th }}$ percentile. They suspect that the convexity in the Nordic countries is related to the strong public education systems that exist in these countries.

\footnotetext{
${ }^{13}$ There are also estimates for many other countries. Examples include the following: Italy has been estimated to have an IGE of about .5 (Piraino (2007), Mocetti (2007)); LeFranc and Trannoy (2005) estimate the IGE for France at about .4. In contrast, much lower estimates have been found for Australia (Leigh 2007), Canada (Corak and Heisz 1999), and Germany (Vogel 2008).

${ }^{14}$ Using Canadian data, Corak and Heisz (1999) show using transition matrices that there is much more mobility in the middle of the distribution than in the tails.

${ }^{15}$ In contrast, Couch and Lillard (2004) find using the PSID that the IGE declines with father's income in the U.S. Bratsberg et al. (2007) use NLSY data for the U.S. and it is not clear why their result differs.
} 


\section{Estimates for Daughter Earnings}

Until lately, most of the literature focused on the intergenerational correlation between fathers and sons, and there were few IGE estimates for daughters. However this situation has changed in recent years. ${ }^{16}$ The bottom half of Table 1 contains the Jantti et al. (2006) estimates for father-daughter elasticities and correlations. We can see that these are smaller than the equivalent father-son ones. ${ }^{17}$ The pattern across countries is similar to that for sons, with smaller IGEs in the Nordic countries and larger ones in the U.S. and U.K.

Raaum et al. (2007) provide a framework to understand why IGEs may differ between women and men. The primary mechanisms are assortative mating and labor supply responses. Assortative mating implies that women from high income families are likely to marry high-earning men, and negative cross-wage or income elasticities of labor supply imply that they then choose fewer hours of work and, as a result, end up with lower labor earnings. ${ }^{18}$ On the other hand, it is generally found that women have higher own-wage labor supply elasticities than men, and this factor tends to raise the female IGE relative to that of men.

Interestingly, Raaum et al. (2007) find that men and women have very similar intergenerational persistence of earnings capacity (as measured by returns-adjusted education) in the U.S., U.K., and Nordic countries. This is consistent with labor supply playing a large role in reducing women's IGE relative to men. Also, they show that,

\footnotetext{
${ }^{16}$ When studying daughters, the focus is sometimes on the effects of father's earnings and sometimes on joint earnings of father and mother.

${ }^{17}$ For the U.S., Mazumder (2005) finds estimates are similar for daughters and sons. However, Scandinavian evidence generally suggests that intergenerational earnings persistence is lower for women than for men when measured by individual earnings. See Österberg (2000), Österbacka (2001), Bratberg et al. (2005, 2007), Raaum et al. (2007), Holmlund (2008), Hirvonen (2008), and Nilsen et al. (2008).

${ }^{18}$ Single women do not experience this cross-wage effect and so should be expected to have higher IGEs than married women.
} 
among married women, U.S. estimates of the relationship between parental income and own earnings are quite similar to those from the Nordic countries and lower than those from the U.K. This surprising finding can be explained by assortative mating, with the cross-wage effects dominating in the U.S. while own-wage labor supply elasticities are more important in the Nordic countries.

\section{Estimates for Family Earnings}

Given the prevalence of two-adult households, total family earnings are, in addition to individual earnings, an important subject of study. Chadwick and Solon (2002) find that, in the U.S., the elasticity of daughters' family earnings with respect to their parents' income is about .4. Here, assortative mating can have a very strong influence. Strikingly, they also show that individual earnings of husbands and wives are as highly correlated with the incomes of their in-laws as with the incomes of their own parents. Ermisch et al. (2006) conclude that about $40 \%$ of family income persistence in the U.K. and Germany results from assortative mating.

We have seen that there are large differences in IGEs across countries for both sons and daughters. Despite differences in the degree of assortative mating and the size of own and cross-wage labor supply elasticities across countries, Raaum et al. (2007) find that the cross-country patterns of intergenerational transmission of family earnings are quite similar to the cross-country patterns of IGEs for sons and daughters. 


\section{Changes in IGEs over Time}

The recent literature has also started to focus on how intergenerational persistence has changed over time. U.S. studies have had to deal with the problems of small sample sizes for specific cohorts and have found little evidence of statistically significant trends over time (Lee and Solon 2009). In the U.K., the available evidence suggests an increase in the IGE for cohorts born between the late 1950s and the 1970s (Blanden et al. 2004, Nicoletti and Ermisch 2007). LeFranc and Trannoy (2005) find no evidence of a trend for France. Bratberg et al. (2005) find some evidence of a decrease in persistence over time in Norway and Pekkala and Lucas (2007) similarly find declines in the IGE in Finland.

Overall, the available evidence suggests no broad trends in persistence across Europe and North America but, possibly, an increase in mobility in Nordic countries coincident with the formation of strong welfare states.

Why the IGE may differ Across Countries and Over Time

Solon (1999) outlines a simple theoretical model, based on Becker and Tomes (1979), that provides an interpretation of the intergenerational earnings correlation. Intergenerational transmission occurs both because higher-earning parents invest more in their children's human capital, and because children of such parents also tend to have higher endowments arising from genetics or from environmental influences in childhood.

More recently, Solon (2004) expands this model to allow for governmental investment in the child's human capital that may be progressive in the sense that the ratio of government investment to parental income decreases with parental income. This model implies that the intergenerational elasticity is increasing in the heritability of earnings- 
related endowments and the earnings return to human capital investment, but is decreasing in the progressivity of government investments. ${ }^{19}$ A significant contribution of this model is that it describes a simple optimizing framework that underlies the standard empirical approach of estimating the IGE.

The Solon (2004) model has four fundamental equations. First, the budget constraint assumes families must allocate all after-tax lifetime income to either parental consumption $\left(C_{0}\right)$ or investment in the child $\left(I_{0}\right)$ :

$$
(1-\tau) Y_{0}=C_{0}+I_{0}
$$

Human capital of the child is produced by a semi-log production function:

$$
h_{1}=\theta \log \left(I_{0}+G_{0}\right)+e_{1}
$$

Here $e_{1}$ is the initial endowment of the child and $G_{0}$ is governmental investment in the child's human capital. Child endowments are assumed to follow an AR(1) process;

$$
e_{1}=\delta+\lambda e_{0}+v_{1}
$$

where $\lambda$ is between 0 and 1 and $v$ is white noise. The earnings equation is

$$
\log \left(Y_{1}\right)=\mu+p h_{1}
$$

where $p$ is the return to a unit of human capital.

The family maximizes utility which equals $U=(1-\alpha) \log \left(C_{0}\right)+\alpha \log \left(Y_{1}\right)$, where $\alpha$ measures the degree of altruism towards the child. Solon (2004) makes an additional parameterization that $G_{0} /\left[(1-\tau) Y_{0}\right]=\varphi-\lambda \log \left(Y_{0}\right)$. A positive value of $\lambda$ signifies that the ratio of government investment to after-tax income is decreasing in income, so $\lambda$ can

\footnotetext{
${ }^{19}$ Ichino et al. (2009) endogenize governmental human capital investments and show that the intergenerational elasticity in any society may be influenced by political economy concerns. Societies where better off families have more influence on the political process will tend to have lower redistributive human capital investments and hence higher intergenerational persistence.
} 
be interpreted as a measure of the progressivity of government spending on children. By maximizing the utility function with respect to parental investment and collecting terms, one arrives at

$$
\log Y_{1}=\mu^{*}+[(1-\gamma) \theta p] \log Y_{0}+p e_{0}
$$

which takes the exact form of the standard IGE regression. Note that equation (8) implies that $\log Y_{0}$ is correlated with the error term in equation (10). Solon (2004) shows that, in steady state where the variance of log earnings is the same in both generations, the probability limit of the OLS estimator of the coefficient on log fathers' earnings in (10) is $\frac{(1-\gamma) \theta p+\lambda}{1+(1-\gamma) \theta p \lambda}$

Thus, the estimated IGE (and intergenerational correlation) will be greater if (1) the heritability coefficient $\lambda$ is higher so ability is more highly correlated across generations, (2) $\theta$ is higher so that the human capital accumulation process is more efficient, (3) earnings returns to human capital are higher so $p$ is larger, or (4) governmental investment in human capital is less progressive so $\gamma$ is smaller.

Given that the heritability of endowments is unlikely to differ significantly across developed countries or over time (and differences in the efficiency of the education system are hard to measure), explanations for differences across countries tend to focus on differences in the returns to skills (primarily education) and differences in government investments. For example, the low IGEs for Nordic countries could be explained either by their compressed earnings distributions (low returns to skills) or by social and 
educational policies regarding childcare and education that tend to equalize educational opportunities for children. ${ }^{20} \mathrm{We}$ focus here on the second type of explanations. ${ }^{21}$

It is widely believed that countries with better public education systems should have lower IGEs. ${ }^{22}$ Ichino et al. (2009) correlate the estimated IGE in 10 countries (Denmark, Finland, Canada, Sweden, Germany, France, U.S., U.K., Spain, and Australia) with public expenditure on education and find it equals -.54; they report that the correlation is even stronger when they focus on public expenditure on primary education. ${ }^{23}$ They also find a large positive cross-country correlation between the richpoor gap in political participation (as measured by membership of a political party) and the IGE. These results suggest that political economy considerations are important in determining policy and thus influencing the IGE. However, given the evidence is purely cross-sectional for only 12 countries, more work in this area is warranted.

Mayer and Lopoo (2008) use the PSID and find that intergenerational earnings elasticities are higher in low per-child spending U.S. states compared to higher-spending ones. ${ }^{24}$ These estimates are robust to including fixed effects for the state the child resided in at age 15 (identification then comes from changes over time in state-level spending). A nice feature of this study is that, because they include state dummies, they are not reliant on cross-sectional variation across states. Future research using more narrowly defined

\footnotetext{
${ }^{20}$ For example, Norway has free public education up to and including University-level as well as a universal subsidized public childcare system.

${ }^{21}$ There is some work that calculates cross-country correlations of returns to education and/or measures of cross-sectional inequality with intergenerational persistence (for example, Blanden, 2009). Unfortunately, given small sample sizes and the fact that countries differ in many ways, this evidence is only suggestive of important labor market factors.

${ }^{22}$ See Davies, Zhang and Zeng (2005) for one theoretical exposition.

${ }^{23}$ Blanden (2009) finds a similar relationship across countries.

${ }^{24}$ They divide the expenditures by the state population aged 0 to 17 to calculate per-child state expenditures in each year. They then average these per-child state expenditures over the 3 years when the child was aged 15 to 17 .
} 
measures of expenditures on children and exogenous sources of variation in these expenditures would be valuable. Also, further work on the differential effects of state investments at various child ages on intergenerational transmission would be useful.

Pekkarinen et al. (2009) test the influence of the education system by examining the effects on the IGE of shifting from an early-tracking schooling system to a comprehensive system. They use the fact that, during the 1970s, a Finnish educational reform was implemented in different regions at different times over a 6-year period. They allow the IGE to depend on which system the child experienced while controlling for cohort and regional effects.

Pre-reform, all students entered primary school at age 7. After four years in the primary school, the students could apply to the general secondary school or continue in the primary school for two more years and, in some schools, continue classes for two further years. Critically, however, students who followed this second education track were not eligible for senior secondary schools or for university-level studies and so either did some vocational training or dropped out. The reform replaced this system with a nineyear comprehensive school that all children attended until age 16. Students then chose whether to apply to upper secondary schools or to vocational schools, and admission to both tracks was based solely on comprehensive school grades. Thus, tracking began much later after the reform. Pekkarinen et al. find that the IGE for sons fell from .3 to .23 as a result of the reform, suggesting that early school tracking reduces intergenerational mobility. The reform also involved curricula changes and increased educational 
attainment, so the exact interpretation is a bit clouded. However, it does provide evidence that the school system matters for the IGE. ${ }^{25}$

Machin (2007) shows that the expansion of higher education in the U.K. in the 1980s and 1990s led to a large increase in the proportion of children of high income families who have college degrees but much smaller change for children of low income families. At the same time, he also shows that earnings mobility was higher for cohorts born in 1958 than for those born in subsequent decades, suggesting a link between access to higher education and intergenerational mobility.

\subsection{Credit Constraints and the IGE}

In the Solon (2004) model of the previous section, families are credit constrained and must reduce current consumption to invest in child human capital. Some recent research has aimed to directly explore the effect of credit constraints on the IGE. Recent work on the theoretical background is provided by Han and Mulligan (2001), Grawe and Mulligan (2002), and Grawe (2004). ${ }^{26}$ If there are no credit constraints, and thus parents can borrow from their children's future earnings, each family will optimally invest in the human capital of their children. If ability raises the marginal productivity of human capital accumulation, it will be optimal to invest more in high ability children. In this case, the IGE will be positive only if child ability and parental earnings are correlated and will depend on the strength of intergenerational ability correlations. If there are credit constraints, however, low income families may not be able to optimally invest in their

\footnotetext{
${ }^{25}$ Holmlund (2008) also finds a reduction in the IGE arising from a similar school reform in Sweden. Consistent with this, Meghir and Palme (2005) find that the Swedish reform had a larger impact on the earnings of children of low-educated fathers.

${ }^{26}$ They themselves build on earlier work by Becker and Tomes (1979) and Mulligan (1997).
} 
children's human capital. As a result, extra income will lead to increased human capital investment. Therefore, we would expect that the IGE would be greater for credit constrained families, suggesting the presence of non-linearities.

Testing this hypothesis is troublesome because it is difficult to identify which families are credit constrained. One approach is to assume that credit constraints are most severe for low income parents. However, Han and Mulligan (2001) point out that this effect may be mitigated because higher earning families are more likely to have high ability children and so may be credit constrained if returns to human capital rise with ability and education is costly. Also, educational policies are often designed so that access to lower levels of human capital formation is essentially free, while higher-level education can be expensive in some countries.

Indeed, Grawe (2004) shows that earnings-ability correlations could lead to varying types of non-linearities, depending on the exact assumptions used. He also shows that, in the absence of credit constraints, there is no reason to believe that the relationship between $y_{1}$ and $y_{0}$ would be linear. Thus, he argues, searching for evidence of credit constraints from non-linearities may be a fruitless exercise. ${ }^{27}$

A possibly more direct approach to testing for credit constraints is to try to identify groups who are more likely to be credit constrained. The model suggests that, for any given parental earnings, high ability children are more likely to be credit constrained. Grawe (2004) proxies ability with child earnings and tests his theory using quantile

\footnotetext{
${ }^{27}$ Bjorklund et al. (2008) use very large Swedish register samples to show that the IGE becomes large in the top percentile of the father's earnings distribution. This particular non-linearity is hard to square with credit constraints as these are people with extremely high incomes.
} 
regression. ${ }^{28}$ Credit constraints should imply that, particularly for sons of low-earning fathers, the IGE is higher at higher conditional quantiles. In fact, he finds the opposite and concludes that there is no evidence for credit constraints in his Canadian data. A disadvantage of this approach is that earnings depend on investments as well as abilities and so are endogenous to the presence of credit constraints.

In another effort to test for evidence of credit constraints, Mulligan (1997) uses PSID data and splits the sample by bequest behavior to create an "unconstrained" group of children who have received or expect to receive bequests of at least $\$ 25,000$ (1989 dollars). He finds this group does not have significantly greater intergenerational mobility, suggesting credit constraints are unimportant. As one possible explanation, Mazumder (2005) notes that it is entirely possible that members of the "unconstrained" group were actually financially constrained when the child was young and this could mitigate the effect. He instead separates families by net worth (under or over the median) using the SIPP data. While he finds larger IGEs for low net worth families, the differences are generally not statistically significant. ${ }^{29}$ Clearly there is a potential payoff to carrying out these exercises with larger datasets so that more precision can be obtained. However, even if the precision issue is dealt with, a more general problem is that any two groups (for example, the high net worth and low net worth groups) will differ along multiple dimensions, and it would dangerous to conclude that differences in IGEs come from credit constraints rather than some other set of factors.

\footnotetext{
${ }^{28} \mathrm{He}$ acknowledges that this is a weak test as heteroskedasticity could lead to non-linearities across the conditional quantiles.

${ }^{29}$ Gaviria (2002), in the PSID, splits the sample using both bequests and family net worth but also generally finds no statistically significant differences.
} 


\subsection{Intergenerational Transmission of Education}

In addition to earnings, educational attainment provides an important source of information about the lives of individuals; as a result, there has been extensive study of intergenerational transmission of education. As a practical matter, education has advantages over earnings in terms of estimation; with education, measurement issues are much less difficult. People tend to complete education by their mid twenties so, unlike with lifetime earnings, analysis can successfully take place when children are relatively early in the life-cycle. Also, non-employment causes no difficulties, and measurement error is likely to be much less of a problem as people tend to know their own educational attainment. Furthermore, there is now an extensive literature that shows that higher education is associated with many other beneficial characteristics such as higher earnings, better health and longer lifespans. ${ }^{30}$

Conceptually, we can think of the educational choice of children as depending on the cost of education, the return to education, and, in the case where families are creditconstrained, on family income. It is commonly assumed that the return to education is higher for high ability children and also for children of highly educated parents. These assumptions imply that children of highly educated parents will tend to choose higher education due both to the direct effect of having more educated parents (which could be interpreted as the causal channel), and the indirect effect of having higher ability. With credit constraints, the higher average income of highly educated parents is yet another reason for a positive relationship between parent and child education.

There are many possible underlying mechanisms that would lead to a direct effect of parental education on child education. First, as mentioned above, higher educated

\footnotetext{
${ }^{30}$ The extent to which these are causal effects is a subject of ongoing research.
} 
parents generally have higher incomes and income may impact educational attainment.

Second, parental education may affect parental time allocation and the productivity of the parent in child-enhancing activities. ${ }^{31}$ Third, education may change bargaining power in the household. More educated mothers may be more successful in directing expenditures towards child-friendly activities and investments. The focus of current research is on establishing a link between parent and child education; understanding the underlying mechanisms is a clear direction for future research.

\section{Estimation Issues}

As mentioned above, compared to earnings, there are fewer difficult estimation issues when studying intergenerational correlations of education. However, there are still choices to be made regarding the measure of intergenerational persistence used. One strategy is to treat educational attainment as a continuous variable and calculate the parent-child correlation. Like the earnings correlation, this has the effect of factoring out the cross-sectional dispersion of education in the two generations. In contrast, the regression coefficient is affected by the relative variance of education across generations. If the standard deviation of education is lower in the parent's generation than in the child's, then the regression coefficient exceeds the correlation. This issue is of practical importance, as there have been large increases in educational attainment in recent decades and these have tended to cause a secular increase in the variance of education. Additionally, Hertz et al. (2007) show that, in recent decades, this secular increase has tended to occur at a decreasing rate, so changes over time in the correlation tend to be

\footnotetext{
${ }^{31}$ Guryan et al. (2008) show, using the American Time Use Survey, that more educated parents spend more time on average with their children.
} 
more positive (or less negative) than changes in the regression coefficient. Reporting both measures seems a sensible solution.

Of course, education is generally measured as a discrete variable and, as such, it is also natural to use methods that explicitly acknowledge that fact. Intergenerational mobility can be measured using transition matrices, where parental education is on one axis and child education on the other. For example, Chevalier et al. (2009) use two different indices that measure different types of mobility across boundaries from one generation to the next. Unfortunately, these indices do not correlate very highly across countries, suggesting one should be cautious about relying too heavily on any one particular index.

Estimates by Country and Over Time

Compared to earnings, there have been fewer advances in the estimation of intergenerational education correlations and elasticities since 1999, in part because there are fewer difficulties associated with timing and measurement. However, the evidence base has improved enormously. Hertz et al. (2007) provide an impressive survey of correlations and regression coefficients for a sample of 42 countries using comparable sample and variable definitions. In Table 2, we have taken Table 2 from their paper. They find that the correlations are highest in South America at about .6. They are typically about .4 in Western Europe, with the lowest estimates being for the Nordic countries. The U.S. estimate is .46 . 
Chevalier et al. (2009) find generally similar results in their more limited sample of European countries and the U.S. ${ }^{32}$ Consistent with theory, they find that intergenerational educational persistence is higher in countries with higher returns to education and lower in countries that spend more public funds on education. Other studies have found that particular features of the schooling system matter. Consistent with findings for earnings mobility, Bauer and Riphahn (2006) find that earlier school tracking increases intergenerational educational persistence using cross-sectional variation in school tracking across cantons in Switzerland. Bauer and Riphahn (2009) also use Swiss data to examine the role of school starting age on the intergenerational transmission of education; they find that early enrolment increases intergenerational educational mobility. This may arise because inequalities in family background have less impact on children once they are in school.

An interesting question is whether intergenerational persistence has changed as educational attainment has increased over time. The evidence here is fairly mixed. Hertz et al. (2007) show that, for their 42 countries, regression coefficients have tended to fall over time, but the correlation coefficients show no time trend. Using Italian data, Checchi et al. (2008) find that the intergenerational educational correlation declined from 0.58 for the oldest cohorts considered (born 1910-14), to 0.47 for the youngest cohorts (born 1970 or after). Blanden and Machin (2004) do not explicitly calculate intergenerational persistence but show that, in the U.K., the recent higher education expansion has disproportionately benefited children from higher income (and presumably, higher

\footnotetext{
${ }^{32}$ The Hertz et al. (2007) and Chevalier et al. (2009) findings are generally consistent with others in the literature. Their finding of higher persistence in South America corroborates Behrman et al. (2001) who found much higher persistence in Brazil and Colombia than in the U.S.
} 
education) families. Heineck and Riphahn (2007) find no significant change in the intergenerational persistence in education in Germany over half a century.

Guell et al. (2007) take a particularly creative approach to investigating changes in intergenerational education mobility in Spain. Because many people with the same surname belong to the same family, there are correlations in education by surname. They find that the information content of surnames has increased over time in Spain, suggesting that there has been an increase in educational persistence despite a large increase in educational attainment. We believe that more work relating the expansion of educational opportunities to intergenerational mobility is warranted.

\section{Section 2: Identifying the Causal Effects of Parental Education and Earnings}

While researchers have been studying the correlations between parents' and children's income and education for many years, much of the recent research has aimed to better understand the causal mechanisms that underlie these correlations. The earliest literature on this tried to disentangle the component due to genetics, which is predetermined, and the component due to an individual's childhood environment. While the prevailing wisdom is that at least part of the observed intergenerational correlation we observe is due to inherited genetic differences across families, quantifying how much is nature versus nurture is still an open question. ${ }^{33}$

More recently, economists have moved beyond the nature/nurture debate and have actually started trying to establish the effect of individual parental attributes on the outcomes of their children. As discussed earlier, understanding the determinants of intergenerational correlations is crucial for the development of appropriate public policy;

\footnotetext{
${ }^{33}$ See Sacerdote (2008) for an alternative and lengthier overview of the nature/nurture literature.
} 
without knowing the mechanisms, it is impossible to understand how to promote change. This is, of course, a much more difficult task, as it is often the case that any particular parental attribute is correlated with a variety of parental characteristics, many of which cannot be observed in the data.

Researchers have taken several different methodological approaches to shed light on the mechanisms and causes that underlie the parent-child correlations we observe. We will consider each of these approaches in turn and discuss what new information they provide. As with our earlier discussion of intergenerational correlations, our focus is on studies that looked at the impact of parental income and education.

\subsection{Method 1: Sibling and Neighborhood Correlations}

Sibling Correlations

Sibling correlations in earnings provide an alternative measure of intergenerational influences. Positive correlations imply that shared genetic and environmental factors cause siblings to be more similar than two random members of society. Recent research has dealt with the same set of measurement issues that were discussed earlier with respect to the IGE - transitory shocks and life-cycle bias. For example, Bjorklund et al. (2010) average over about 8 earnings observations per person (to reduce the role of transitory variation) and center these at age 34 (to minimize lifecycle bias).

The consensus value of the correlation of log earnings between brothers in the U.S. of about 4 does not seem to have changed much since Solon (1999). Mazumder (2008) finds brother correlations of almost .5 in the NLSY and about .4 in the PSID. 
Bjorklund et al. (2002) compare sibling correlations across several countries and find estimates of just over .4 for the U.S. and, consistent with the findings for intergenerational elasticities, much lower estimates for Nordic countries. Using a large Norwegian sample, Raaum, Salvanes and Sorensen (2006) find sibling correlations in log earnings of about .2 for brothers and .15 for sisters.$^{34}$ These sibling correlations provide further evidence that family background factors are more important in the U.S. than in the Nordic countries.

One can then use these estimates to try to identify different components, including the IGE. The sibling correlation in earnings can be shown to equal $\rho=\beta^{2}+s$ where $\beta$ is the IGE and $s$ is a measure of all variables shared by siblings that are unrelated to parental earnings (Solon, 1999). If we assume an IGE of about .5 for the U.S. and a sibling correlation of .4, the formula implies that about five eights of the sibling correlation can be attributed to father's earnings, leaving a sizeable role for other shared variables. ${ }^{35}$ One component of $s$ that has been studied is neighborhood.

\section{Neighborhood Correlations}

Page and Solon (2003a) explore how much of the brother correlation in earnings can be attributed to the fact that brothers grow up in the same neighborhood. They use the PSID and exploit the cluster-based sampling procedure that implies that several households in the same small area are included in the data. They use 5-year averages of $\log$ earnings and adjust for point in the life-cycle. They estimate a correlation in adult

\footnotetext{
${ }^{34}$ For education, Raaum, Salvanes and Sorensen (2006) find sibling correlations of about .4 for brothers and close to .5 for sisters. These are somewhat smaller than analogous correlations for the U.S. (Solon 1999).

${ }^{35}$ This does not imply that father's earnings have a causal effect on son's earnings, as it may be other family background characteristics that are correlated with earnings that are relevant.
} 
earnings of .16 for unrelated boys in the same neighborhood - this is about half their estimate of the brother correlation. Interestingly, a large proportion of the neighborhood correlation is accounted for by the fact that boys born in urban areas tend to stay in urban areas and urban earnings are higher. Thus, it appears that coming from an urban area is significant but exactly what neighborhood one is from is less relevant. It is important to remember that neighborhood correlations are an upper bound on true neighborhood effects, as other family traits are likely correlated within neighborhoods.

Raaum, Salvanes and Sørensen (2006) carry out a similar exercise using much larger samples from Norwegian register data. They find that neighborhood correlations in log earnings are much lower in Norway at about .05 for boys and so are not a primary determinant of brother correlations in earnings ${ }^{36}$ Similarly, studying the Canadian city of Toronto, Oreopoulos (2003) finds neighborhood correlations that are very close to zero.

The findings for neighborhood correlations in education also show small effects. Solon et al. (2000) find neighborhood correlations in educational attainment of only about .1 in the PSID. Raaum, Salvanes and Sørensen (2006) find even smaller neighborhood correlations in Norway. Overall, the literature suggests that neighborhood characteristics are not a predominant factor for explaining sibling similarities in adult earnings or education.

It is important to note that none of the sibling or neighborhood correlation studies attempts to distinguish a causal relationship. Given that sibling correlations can arise from common genetic or environmental factors (or interactions between the two), they are not very helpful for pinning down causal mechanisms. The findings of very low

\footnotetext{
${ }^{36}$ It has also been found that neighbourhood correlations have very limited explanatory power for sister correlations in family income (Page and Solon (2003b)) or earnings (Raaum, Salvanes and Sørensen (2006)).
} 
neighborhood correlations have the advantage of ruling out the predominance of geographic factors but leave open the question of why outcomes within families are highly correlated.

\subsection{Method 2: Structural Analysis of Different Types of Siblings}

In and of themselves, sibling and neighborhood correlations are not useful for distinguishing between nature and nurture. A major advance in understanding the nature/nurture distinction is research by Bjorklund et al. (2005); using extremely rich Swedish data, they make use of correlations across a wide range of sibling types, including identical (also called monozygotic) and fraternal (dizygotic) twins, full siblings, half siblings, and adopted siblings, both raised together and raised apart, in order to distinguish nature from nurture. ${ }^{37}$

To get a sense of the approach, consider the following simple additive model

$$
y_{i}=g G_{i}+s S_{i}+u U_{i}
$$

where $G$ represents the genetic factor, $S$ is an environmental factor that is at least partly shared by siblings, and $U$ is an environmental factor that is completely idiosyncratic to the individual (i.e. not at all shared by siblings). Each of these variables, along with $y$, is standardized to have mean 0 and variance 1 . The three factors are unobserved, as are the parameters $g, s, u$ that determine the relative importance of each of the factors. The model assumes that the three factors affect log earnings linearly and additively.

In their most basic model they make the following strong assumptions:

\footnotetext{
${ }^{37}$ The authors build on some older work done by economists during the 1970s. See, for example, Behrman et al. (1977).
} 
1. $G, S$, and $U$ are independent of each other for each individual and, within sibling pairs, all the cross covariances are zero. This assumption implies that having a better genetic endowment does not make it more likely that one has a better environment or ones sibling has a better environment.

2. Identical twins are genetically identical and fraternal twins, like all genetic siblings, share half of their genes. Half-sibling share $1 / 4$ of the same genes, and adopted children have no genetic link.

3. Sibling pairs raised together share the same $S$, while sibling pairs raised apart have uncorrelated environments.

Using these assumptions, it is easy to calculate the following covariances: $\operatorname{cov}\left(\mathrm{y}_{\mathrm{i}}, \mathrm{y}_{\mathrm{j}}\right)$ equals $\mathrm{g}^{2}+\mathrm{s}^{2}$ for monozygotic twins raised together, $.5 \mathrm{~g}^{2}+\mathrm{s}^{2}$ for dizygotic twins and non-twin full siblings raised together, $.25 \mathrm{~g}^{2}+\mathrm{s}^{2}$ for half-siblings raised together, $\mathrm{s}^{2}$ for sibling pairs in which one is adopted, $\mathrm{g}^{2}$ for monozygotic twins raised apart, $.5 \mathrm{~g}^{2}$ for dizygotic twins and non-twin full siblings raised apart, and $.25 \mathrm{~g}^{2}$ for half-siblings raised apart. Also, note that the variance of earnings in the sample equals $\mathrm{g}^{2}+\mathrm{s}^{2}+\mathrm{u}^{2}$.

Given the empirical correlations, one can calculate the values of $\mathrm{g}$, $\mathrm{s}$, and $\mathrm{u}$ from these equations. Indeed, there are several different ways in which they can be calculated, so the authors use minimum distance estimation and weight by the number of observations to efficiently solve this overidentified set of equations. They estimate $\mathrm{g}^{2}=.28$ (.08) and $\mathrm{s}^{2}=.04$ (.04) for brothers, implying that genes are more important than shared environment.

The model fits surprisingly well given the strong assumptions. For example, Assumption 1 is violated if people with good genetic endowments are also more likely to 
have privileged environments and Assumption 2 is violated by assortative mating (people tend to marry people with similar characteristics and so likely share genetic characteristics). ${ }^{38}$

Given this, the authors estimate several less restrictive models. Model 2 estimates the correlation between genes and shared environment rather than assuming it to be zero. Model 3 estimates the genetic correlations between dizygotic twins and non-twin full siblings, half-siblings, and adoptive siblings rather than assuming them to be $.5, .25$, and 0 respectively. Model 4 relaxes the assumption that $\operatorname{cov}\left(\mathrm{S}_{\mathrm{i}}, \mathrm{S}_{\mathrm{j}}\right)=1$ for all sibling pairs that are raised together and zero for all sibling pairs raised apart and instead estimates separate parameters for different sibling types. They find that Model 4 is the only one to provide substantially different estimates from Model 1 with estimates of $\mathrm{g}^{2}=.20(.16)$ and $\mathrm{s}^{2}=.16(.16)$ for brothers. ${ }^{39}$ However, these parameters are rather imprecisely estimated.

The authors find that, while there is a significant role for genetic and shared environmental factors, the biggest role by far is played by non-shared environmental factors (remember that $u^{2}=1-g^{2}-s^{2}$ and even the monozygotic twin correlation is only .36). However, they only have information on 3 years of data, so downward biases in the correlations resulting from transitory measurement error may be partly contributing to this result.

This approach to separating out genetic and environmental effects relies on strong assumptions. Also, as stressed by Sacerdote (2008), this type of methodology is limited to

\footnotetext{
${ }^{38}$ Other violations occur if twins are treated more similarly than non-twins or MZ twins are treated more similarly than DZ twins, if adoptive children are not randomly placed in new homes, or if twins raised apart have been reared together after birth for some time (in the data, twins are deemed to have been raised apart if they were split before age 10).

${ }^{39}$ It is perhaps surprising that allowing gene-environment correlations in model 2 makes little difference. Dickens and Flynn (2001) and Lizzeri and Siniscalchi (2008) develop models that suggest that genetic endowments endogenously affect environmental influences.
} 
decomposing the variances that exist in the sample and the results may not extrapolate to policy changes that are outside this range. In this particular case, environmental variation in Sweden may be quite limited compared to, say, a sample that also includes persons from other countries. The evidence so far suggests that both nature and nurture are important in determining earnings and the relative role of these factors may become more precisely estimated as better datasets become available.

\subsection{Method 3: Decompositions of Intergenerational Persistence}

Various studies have carried out decompositions of the IGE to assess the role of intermediate variables. The basic idea is to see how much of the IGE can be explained by the effect of parental earnings on an intermediate outcome, and the effect of the intermediate outcome on child earnings. Bowles and Gintis (2002) note that the intergenerational income correlation can be decomposed into additive direct and indirect effects. The direct effect is the effect that parents' income has directly on the income of their children, while the indirect effect is the effect of parents' income on intermediate variables that ultimately affect children's income. Bowles and Gintis treat both IQ test scores and education as intermediate variables, among other variables.

Consider a regression of log earnings of sons $\left(y_{1}\right)$ on log earnings of fathers $\left(y_{0}\right)$, education of sons $\left(s_{1}\right)$, and cognitive achievement of sons $\left(c_{1}\right)$. Assume all these variables have been normalized to have mean zero and variance of 1 so that we can write

$$
y_{1}=\beta_{y_{1} y_{0}} y_{0}+\beta_{y_{1} s_{1}} s_{1}+\beta_{y_{1} c_{1}} c_{1}+\varepsilon_{y_{1}}
$$

From this, we can decompose the intergenerational correlation of log earnings into

$$
\rho_{y}=\beta_{y_{1} y_{0}}+r_{s_{1} y_{0}} \beta_{y_{1} s_{1}}+r_{c_{1} y_{0}} \beta_{y_{1} c_{1}}
$$


Where $r_{s_{1} y_{0}}$ is the correlation between the log earnings of the father and the schooling of the son, and $r_{c_{1} y_{0}}$ is the correlation between the log earnings of the father and the cognitive ability of the son.

Using this simplified decomposition combined with estimates of the relevant standardized parameters and correlations obtained from existing studies, Bowles and Gintis (2002) conclude that IQ and educational attainment can explain at most three-fifths of the intergenerational transmission of earnings. Further, by making assumptions about the heritability of IQ scores, they show that genetic transmission can only explain a small proportion of the IGE because IQ scores do not have strong explanatory power for earnings. ${ }^{40}$ However, this does not imply that other genetic factors are unimportant. Even more recently, work by Blanden, Gregg, and Macmillan (2007) examines the role of non-cognitive skills and ability for intergenerational income persistence in Britain. In their work, they demonstrate that covariates can account for approximately half of the estimated intergenerational income elasticity (of .32), with a sizeable portion attributable to cognitive and non-cognitive skills that work through educational attainment. $^{41}$

It is difficult to interpret these decompositions, as the intermediate variables have both genetic and environmental underpinnings and the approach provides no way of getting at causal effects. There is no reason to believe that the OLS regressions that

\footnotetext{
${ }^{40}$ Much of the behavioural genetics literature has attempted to estimate the genetic and environmental component of IQ scores. Sacerdote (2008) reports a range of estimates from the literature in which the genetic component of IQ is generally found to be in the 50-60\% range with shared environmental influences being somewhere between 5 and $30 \%$. These suggest IQ is strongly genetically determined but the models rely on strong assumptions.

${ }^{41}$ Other decompositions of the IGE have utilized health (Eriksson et al. 2005) and personality (Groves 2005) as intermediate variables.
} 
underpin the methodology provide consistent estimates, as there are likely to be many omitted variables. As such, we find the evidence from these approaches to be suggestive but not a compelling source of evidence on causal mechanisms.

\subsection{Method 4: Sibling and Twin Differences}

A concern with using simple regression techniques to identify the sources of the intergenerational correlations we observe is omitted variable bias; to the extent that the estimated model is missing variables that are correlated with included variables, our estimates will be inconsistent. One solution is to control for a sufficiently large number of covariates, leaving only one or a few identifiable sources of variation.

In an effort to approximate this, the literature has moved to looking within sibling pairs, thereby eliminating bias due to the omission of fixed family characteristics. The perceived "gold standard" in this area uses arguably exogenous variation in education within monozygotic twin pairs to examine the role of mothers' education on the education

of their children. ${ }^{42}$ By using data on pairs of identical twin mothers, one can effectively "difference out" not just fixed family characteristics but also any differences due to genetics of the mother.

A very simple model takes the form:

$$
S_{1 i j}=\delta_{1} S_{0 j}+\Gamma_{1} h_{0 j}+\varepsilon_{i j}
$$

for child $i$ in family $j$, where $S_{0 j}$ is the schooling of the mother, $h_{0 j}$ reflects other endowments of the mother that are correlated with child schooling (some observed, some unobserved), and $\varepsilon$ represents child-specific characteristics. To the extent that the

\footnotetext{
${ }^{42}$ There is very little literature that uses this approach to study the effect of parental earnings on child outcomes. Therefore, we restrict our attention to parental education in this section.
} 
unobserved endowment of the mother is correlated with her schooling outcome, OLS estimates of $\delta_{1}$ will be biased. Comparing identical twin mothers, in this case, would enable one to difference out the $\Gamma_{1} h_{0 j}$ term, obtaining a consistent estimate of $\delta_{1}$ (assuming $S_{0 j}$ is uncorrelated with the error term conditional on the fixed effects).

However, this leaves out the role of the father's education and earnings. If there is assortative matching, then estimates of $\delta_{1}$ will represent the effect on child's outcomes of increasing mother's education, inclusive of the effects on who she marries. To net out the effect of assortative mating, one can control for father's education and other characteristics of the father. Note that, in the context of the twin mother fixed effects, identification of the effects of father's education is based on the difference in education between the husbands of the twin mothers.

Behrman and Rosenzweig (2002) implement this methodology using monozygotic twins from the Minnesota Twins Register. Their simple OLS estimates, controlling for father's schooling and father's log earnings, suggest a positive and significant relationship between parents' and children's schooling (with a coefficient of 0.33 on mother's schooling and coefficient of 0.47 on father's schooling, both significant, when run separately). However, once they add twin mother fixed effects to look within female monozygotic twin pairs, thereby differencing out any genetic factors that influence children's schooling, the coefficient on mother's schooling turns negative and almost significant. The analogous fixed effects exercise using male monozygotic twin pairs gives coefficients for father's education that are about the same size as the OLS estimates. One interpretation of these estimates is that more educated women are more likely to participate in the labor market and this has a negative impact on their children. 
However, recent work by Antonovics and Goldberger (2005) calls into question these results and suggests that the findings (particularly the negative effect of mother's education) are quite sensitive to the coding of the data.

Most recently, Bingley, Christensen and Jensen (2009) use Danish registry data with information on twin type (identical versus fraternal) to examine both the short- and long-run effects of parents education on children's outcomes. They find a shift in the relationship between parents' education and children's education over time; for parents born before 1945, they find results consistent with those of Antonovics and Goldberger that fathers' education has a positive effect on children's outcomes with no effect of mother's education. However, for more recent cohorts, they find that mothers' schooling has a positive effect but there is no effect of fathers' schooling.

Table 3, Panel A presents a summary of the findings from the twins/sibling studies of educational transmission. ${ }^{43}$ While the twins research is quite innovative, it is important to note that it is reliant on strong assumptions. For example, it may be unrealistic to assume that twins differ in terms of education but not in terms of any other characteristic or experience that may influence the education of their offspring. Even monozygotic twins may differ in terms of personality and their degree of familyorientation. Certainly there can be large birth weight differences between identical twins, and these have been shown to be correlated with their schooling attainment and earnings. ${ }^{44}$ It is also plausible that one twin is treated differently from the other based on their endowments, with parents making either compensatory or reinforcing investments.

\footnotetext{
${ }^{43}$ Note that this table is adapted from Holmlund, Lindahl, and Plug (2008), with their estimates added as the last entry of each panel.

${ }^{44}$ See work by Behrman and Rosenzweig (2004), Black, Devereux, and Salvanes (2007), and Royer (2009).
} 
All these issues have been highlighted in the returns to education literature. (See Griliches, 1979 and Bound and Solon, 1999 for demonstrations that biases using sibling and twin fixed effects may be as big or bigger than OLS biases. $)^{45}$

In the intergenerational case, there are further complications. One additional issue that the offspring's outcomes are affected by both the twin and his or her mate and it is impossible to fully control for all characteristics of the mate. Given assortative mating, unobserved characteristics of the mate are likely correlated with education of both parents, leading to bias even with twin fixed effects. Another issue is that children of twin sisters (who are first cousins) may interact frequently and be influenced by each other and their aunt. If, for example, twin sisters are closer than twin brothers, this could bias downwards the effect of mother's education relative to that of father's. This provides a possible explanation for findings of weak effects of mother's education in this literature.

\subsection{Method 5: Regression Analysis using Adoptees}

Another strand of literature aimed at understanding causal processes incorporates data on adoptees. If we assume that (1) adopted children are randomly assigned to families as infants and (2) adopted children are treated exactly the same as biological children, then adoption can be considered an experimental intervention that randomly assigns children to families. This type of intervention is very large compared to other experiments; for example the Moving to Opportunity (MTO) experiment shifted children from one neighborhood to another but generally began in adolescence and did not change their family members. Other interventions affect children's peer groups in school but do

\footnotetext{
${ }^{45}$ Twin fixed effects exacerbate problems with measurement error in parental education. There are also issues of external validity as twins are, on average, different in some respects from the rest of the population. For example, they tend to have much lower birth weight.
} 
not affect the school attended, the neighborhood lived in, or the family unit. Adoption takes a child in infancy and assigns them to a family, and in the process largely determines what type of area they will live in, what type of friends they will have, and what type of schools they will attend.

\section{Bivariate Regression Approach}

There are several variations of the regression approach. One is to estimate the following bivariate regression separately for adopted children and their non-adopted siblings:

$$
y_{1}=\alpha+\lambda y_{0}+\varepsilon
$$

where $y_{1}$ is some outcome variable for the child (for example, log earnings), and $y_{0}$ is the analogous variable for the adoptive parent. The comparison is then made between the value of $\lambda$ for adoptees and non-adoptees. If nurture is unimportant, we would expect $\lambda$ to be zero for adoptees and positive for non-adoptees (because of the genetic correlation between parent and child). If genetics and endowments in infancy are unimportant, we would expect $\lambda$ to be positive and equal for adoptees and non-adoptees. Therefore, the relative value of $\lambda$ for the two groups gives an indication of the importance of nature versus nurture. A nice feature of equation (14) when earnings are studied is that it is precisely the equation used to estimate the IGE and so the estimate of $\lambda$ for adoptees is an estimate of what the IGE would be if all genetic influences were absent.

However, for the most part, adoptees are not randomly placed with families. Sacerdote (2007) uses data from a rare case with plausibly random assignment; the adoptees in the study are Korean-Americans who were placed with American families 
between 1970 and 1980 . The adoption agency used a first-come first-served policy to assign adoptees to families. Thus, children are randomly assigned to families, conditional on the family being deemed suitable by the agency. When child's years of education is regressed on mother's years of education, the coefficient for non-adoptees is .32, while it is .09 for adoptees, suggesting genetics and infant endowments are more important than nurture in determining educational attainment. ${ }^{46}$ One point worth noting is that to be allowed adopt, families are screened by the adoption agency. Therefore, it is likely that differences in observables between families overstate true differences between families; families with poor observables who are allowed adopt are likely to have higher than average unobserved characteristics. This factor would tend to move all the estimates towards zero. ${ }^{47}$

Plug (2004) finds larger coefficients of about .28 on adoptive mother's education using a sample of adopted children who graduated from high schools in Wisconsin in 1957 from the Wisconsin Longitudinal Survey (WLS); given assignment is not random, these larger coefficients may result from positive selection of better endowed children into more educated families. ${ }^{48}$

There are mixed findings for parental income using this approach. Bjorklund et al. (2006) find estimates for Sweden that suggest strong effects of adoptive parent's income

\footnotetext{
${ }^{46}$ Earlier studies by Sacerdote $(2000,2002)$ carry out similar analysis using small datasets but the estimates tend to be imprecisely estimated. Using the NLSY, he finds larger effects of mother's education for adoptees of .22; this compares with a coefficient of . 35 for non-adoptees. However, there is no reason to expect random assignment in these data.

${ }^{47}$ Similar in spirit to the adoptions analysis, Bjorklund and Chadwick (2003) use Swedish data to analyze income elasticities of both intact and separated families. They find that sons who have always lived with their biological fathers have an IGE of 0.25 , sons who sometimes lived with their biological fathers have an elasticity of about 0.20 , and sons who never lived with their biological fathers have a very low elasticity not significantly different from zero. These estimates are consistent with the idea that nurture is very important in determining the IGE. A caveat, of course, is that the group of sons who live apart from their father is non-random.

${ }^{48}$ He finds similar sized effects for father's education and, when both father and mother's education are included together, the effect of father's education dominates.
} 
on log income while Liu and Zeng (2009) find little evidence in the PSID that adoptive parent income matters. These could reflect true transmission differences across the two countries or, given neither study has random assignment, could relate to differences in the adoption selection process. ${ }^{49}$

\section{Multivariate Regression Approach}

Researchers also estimate multivariate regressions using adoptees in an attempt to determine which particular parental characteristics matter most. The equation tends to look like

$$
y_{1}=\alpha+\lambda_{1} S_{0}^{m}+\lambda_{2} S_{0}^{f}+\lambda_{3} Z+\varepsilon
$$

Where $S_{0}^{m}$ and $S_{0}^{f}$ refer to education of mother and father respectively, and $\mathrm{Z}$ refers to other characteristics such as family income and family size. However, it is important to note that the adoption experiment cannot generally be used to identify the causal effects of specific environmental factors on child outcomes. Suppose we are interested in knowing whether maternal education matters. While some infants are assigned to highly educated mothers and others to mothers with low education, the difference in outcomes cannot be used to infer the effects of maternal education because highly educated parents will also typically have higher incomes, live in better areas, etc. Given it is impossible to control for all the possible parental characteristics that are correlated with education, one cannot in general identify the causal effect of education.

Table 3, Panel B presents a summary of the studies in this area. Using multiple regression, Sacerdote (2007) finds that the adoptive family characteristics that matter

\footnotetext{
${ }^{49}$ In his U.S. study, Sacerdote (2007), who plausibly does have random assignment, finds a log household income elasticity for adoptive children of .19 but it is statistically insignificant.
} 
most for child education are mother's education (1 extra year of maternal education increase child education by .09) and family size ( 1 extra child reduces education by .12 of a year). He finds no effect of family income. Plug and Vijverberg (2005) find a positive effect of family income on education using the WLS but it is imprecisely estimated and is consistent with very small effects. Using the same dataset, Plug (2004) finds, using multiple regression, that the education of adoptive fathers influences child education but the education of adoptive mothers has no statistically significant impact.

While this method may not convincingly pin down the effect of any one particular parental characteristic, the adoption approach is very useful for estimating the general importance of being placed in a high socio-economic status family. If one carefully defines the treatment in this way, one can estimate causal effects. For example, Sacerdote (2007) defines the treatment as being assigned to a family with three or fewer children and high parental education and can estimate the causal effect of being assigned to a family of that type. He finds that being assigned to the high educated, low family size type family increases the likelihood of graduating from college by $16 \%$ compared to being assigned to a large family in which neither parent has a college degree. We can be confident that family type matters a lot; however, one cannot be sure which components matter most.

\section{Using Information on Biological and Adoptive Parents}

A third type of analysis uses information on both biological and adoptive parents to run regressions such as the following on adopted children:

$$
y_{1}=\alpha+\lambda_{a} y_{0 a}+\lambda_{b} y_{0 b}+\varepsilon
$$


Where $a$ references adoptive parents and $b$ references biological parents. This model allows a direct comparison of the influence of the characteristics of biological and adoptive parents. Bjorklund et al. (2006) estimate separate models for years of schooling, whether or not the child obtains a university degree, earnings, and income using a population dataset of Swedish adoptees. This is an important study, as it is rare to have data on both biological and adoptive parents for each child. We present their estimates in Table 4. They find similar size effects for biological fathers and adoptive fathers when the dependent variable studied is years of education or university degree. Biological mothers have bigger effects than adoptive mothers on education. However, adoptive fathers have a larger impact than biological fathers on earnings and income. These positive effects of adoptive parents suggest that environmental factors are important. An intriguing result is that the sum of the effects for biological and adoptive parents is generally similar to the effect of parents on non-adopted children. This is consistent with the absence of significant interactions between characteristics of biological and adoptive parents. However, when the authors include these interactions in the regressions, they generally are positive and statistically significant and indicate the presence of nature-nurture interactions. This is an important result, as it implies that additive models of genetic and environment factors (such as twin fixed effects methods) are misspecified. In contrast, Bjorklund et al. (2007), also using Swedish data, find evidence that the linear additive model fits well. ${ }^{50}$ Further research is definitely warranted. Overall, the findings of these studies, and from the adoptions literature more generally, suggest that both environmental and genetic factors are important.

\footnotetext{
${ }^{50}$ Note, however, that neither study has random assignment of children to parents and this could potentially bias results.
} 


\subsection{Method 6: Natural Experiments/Instrumental Variable Estimates}

Another method used to identify causation involves finding variation in parents' education and income that is arguably unrelated to other parental characteristics and using this variation to identify the effect of income/education on the outcomes of children.

Income

Despite the extensive literature on the correlation between parents and children's income, there is still little compelling work on the direct causal role of parents' income on children's outcomes. This is undoubtedly because it is difficult to isolate "random" shocks to family income. While there are a number of shocks to family income induced by divorce, job layoffs, and death, these are also likely to have direct affects on children's outcomes.

The literature has gone in two directions in trying to identify the causal role of parent's income on children's income and children's outcomes more generally. The first is to look at the effect of income provided through welfare programs on children's outcomes. The second has focused instead on the overall effect of events that shock income (among other things) on the outcomes of children.

The effect of welfare income and other forms of public support on children's outcomes is discussed in more detail in the chapter by Almond and Currie in this volume. There are a number of recent papers using U.S. data that find evidence that income provided through welfare or Earned Income Tax Credit (EITC) benefits does influence 
the outcomes of children. These include work by Dahl and Lochner (2005) who look at the EITC and work by Morris, Duncan, and Rodrigues (2004) who use pooled microdata from four studies that evaluated eight welfare and antipoverty programs. ${ }^{51}$

The second literature has focused on the role of income shocks induced by the labor market status of a parent. Using U.S. data, Shea (2000) attempts to isolate the role of income on the human capital of children by using variation induced by what he argues to be "luck" - union status, industry, and job loss. He concludes that variation in parents' income due to luck has little to no effect on children's human capital, although there is some effect for children of low-educated fathers.

Oreopoulos, Page and Stevens (2008) use a Canadian administrative panel to examine the effect of father's displacement from work on the outcomes of their children. They are careful to note that this incorporates not only the shock to income the family experiences but any associated psychological costs in terms of discouragement, etc. They find that sons whose fathers were displaced have annual earnings that are about $9 \%$ lower than similar children whose fathers did not experience an employment shock; they are also more likely to receive unemployment insurance. These estimates are driven by the experiences of children whose family income was at the bottom of the income distribution. $^{52}$

Rege, Telle, and Votruba (2007) use Norwegian data to estimate the effect of parental job loss due to plant closure on the outcomes of children. They find that father's job loss leads to a decline in the children's graduation GPA; however, they suggest that it

\footnotetext{
${ }^{51}$ See Almond and Currie (this volume) for more detailed descriptions and references.

${ }^{52}$ In contrast, using Norwegian data, Bratberg et al. (2008) find that, although job displacement reduces the earnings of fathers, it does not affect the later earnings of their children.
} 
is not due to income loss, divorce, or relocation. ${ }^{53}$ They also find that mothers' job loss leads to improved school performance, suggesting that time inputs may be more important than financial ones.

Overall, the results suggest that the long-term consequences of unexpected job loss extend beyond the effect on one's own income to the eventual labor market outcomes of one's children. However, given that job loss has many impacts other than its effect on income, these results do not conclusively indicate a causal effect of family income on child outcomes.

\section{Education}

The instrumental variables approach has been much more widely used to look at the causal relationship between parents' and child's education. In this case, the education of the parents is "shocked" by some exogenous force (such as a policy change) and one can see the later effects on the children. Table 3 , Panel C provides a summary of the studies in this area.

In Black, Devereux, and Salvanes (2005), we apply this approach using register data from Norway. During the 1960s, there was a change in the compulsory schooling laws affecting primary and middle schools. Pre-reform, the Norwegian education system required children to attend school through the seventh grade; after the reform, this was extended to the ninth grade, adding two years of required schooling. Additionally, implementation of the reform occurred in different municipalities at different times, starting in 1960 and continuing through 1972, allowing for regional as well as time series

\footnotetext{
${ }^{53}$ Consistent with this, Loken (2010) finds that children from families whose incomes were increased as a result of the Norwegian oil boom in the 1970s did not subsequently achieve higher educational attainment.
} 
variation. As a result, the reform provides variation in parental education that is exogenous to parental ability and enables us to determine the impact of increasing parental education on children's schooling decisions.

The empirical model is summarized by the following two equations:

$S_{1}=\beta_{0}+\beta_{1} S_{0}+\beta_{2} A G E_{1}+\beta_{3} A G E_{0}+\beta_{4} M_{M N I C I P A L I T Y}+\varepsilon$

$S_{0}=\alpha_{0}+\alpha_{1} R_{E F O R M_{0}}+\alpha_{2} A G E_{1}+\alpha_{3} A G E_{0}+\alpha_{4}$ MUNICIPALITY $_{0}+v(18)$

In equations (17) and (18), $S$ is number of years of education, AGE refers to a full set of years of age indicators, MUNICIPALITY refers to a full set of municipality indicators, and REFORM equals 1 if the individual was affected by the education reform, and 0 otherwise. In all cases, the subscript 0 denotes parent and the subscript 1 denotes the child. We estimate the model by parent gender and child gender using Two Stage Least Squares (2SLS) so that equation (18) is the first stage and REFORM ${ }_{0}$ serves as an instrumental variable for $S_{0}$. Despite strong OLS relationships, we find little evidence of a causal relationship between parent education and child education. ${ }^{54}$

Oreopoulos, Page, and Stevens (2006) use a similar methodology to examine the influence of parental compulsory schooling on grade retention status for children aged 7 to 15 using the 1960, 1970 and 1980 U.S. Censuses. They study U.S. law changes (that occurred in different states at different times) to identify the effect of parents' educational attainment on children's school performance (as proxied by grade-for-age). They find that an increase in parental education attainment of 1 year reduces the probability that a child repeats a grade by between 2 and 7 percentage points and their IV estimates are more negative than the OLS ones.

\footnotetext{
${ }^{54}$ However, there is evidence in some specifications of a positive causal impact of mother's education on son's education.
} 
Chevalier (2004) uses a change in the compulsory schooling laws in Britain that occurred in 1972. Because the legislation was implemented nationwide, there is no crosssectional variation in the British compulsory schooling law and the identifying variation in parental education arises both from secular trends in education and the once-off change in the law. He finds a large positive effect of mother's education on her child's education but no significant effect of paternal education. ${ }^{55}$

Other work has used different types of arguably exogenous variation in parental education to identify intergenerational mobility in education. Maurin and McNally (2008) use variation in college attendance induced by the student riots in May 1968 in Paris; because of student protests, students and authorities negotiated for more lenient exam standards for the baccalaureat exam (which, if successfully completed, guarantees access to university) for that year alone. As a result, the pass rate increased significantly for that year and more students were able to attend college. This led to significantly higher wages for the students who were then able to attend college, with an increase of about $14 \%$. In addition, these returns were passed on to the next generation; grade repetition declined significantly for the children of the affected cohort.

Carneiro, Meghir, and Parey (2007) use the NLSY79 and variation in maternal education induced by variation in schooling costs at the time the mother was growing up to identify the effect of maternal education on a variety of children's outcomes, including behavioral problems, achievement, grade repetition, and obesity. They find that, among children aged 7-8, an increase in mother's education by one year increases math

\footnotetext{
${ }^{55}$ Work by Chevalier et al. (2005) combines the instrument for parental education used in Chevalier (2003) and union status of the father as an instrument for father's income (as used in Shea (2000)) and concludes that income matters more than education for children's outcomes.
} 
standardized test performance by 0.1 of a standard deviation and reduces the incidence of behavioral problems.

Magnuson (2007) uses random assignment into a "human capital development" program for welfare mothers as an instrument for mother's educational attainment and finds evidence of an effect of mother's education on children's academic school readiness.

Finally, recent work by Page (2009) uses cohort level variation in schooling levels induced by the G.I. Bill in order to identify the intergenerational transmission of education. She argues that this variation was due to the timing of the draft and not unobservable individual characteristics or underlying trends. She finds that a one year increase in father's schooling reduces the probability that his child repeats a grade by $2-4$ percentage points. This is quite consistent with her earlier work with Oreopoulos and Stevens, suggesting that the timing of the additional year--either in high school due to increased compulsory schooling or in college through GI benefits--does not affect the estimates.

\section{Parental Education and Infant Health}

There are also studies of the effect of parental education on infant health. While they only study outcomes of children when they are infants, they can still be relevant to intergenerational transmission; as noted above, it has been fairly well established that better infant health has a positive causal effect on later adult outcomes. McCrary and Royer (2006) use a regression discontinuity design with data from California and Texas and compare women born just before and just after school entry dates - the latter group 
start school a year later and subsequently end up with lower education on average. Using this as the basis for an instrumental variable strategy, they find no effect of education on fertility or age-at-first-birth and very small and statistically insignificant effects of education on infant health as measured by birth weight. This particular instrument largely relies on educational variation for low educated women. ${ }^{56}$

In contrast, Currie and Moretti (2003) also use U.S. data and find that higher maternal education reduces the number of children mothers have had at any particular age and the probability their child has low birth weight. They also use an instrumental variables strategy but are more focused on the top end of the education distribution, as their instrument is whether there is a college in the woman's county when she is aged 17. Given they use county fixed effects, identification comes from college openings. It is plausible that the differences between the findings of the two studies reflect non-linear effects of maternal education on child health. Thus, the evidence suggests that increasing education by making compulsory schooling laws stricter is unlikely to have much impact on later child outcomes through the infant health channel. However, an expansion of college opportunity may indeed benefit long-run outcomes of children.

\section{Limitations of the IV Approach}

There are a number of limitations to the instrumental variables approach, but two stand out as being the most important. The first is the credibility of the instrument; while it is not difficult to determine whether the instrument has a strong first stage, the excludability of the instrument is inherently untestable. For example, changes in

\footnotetext{
${ }^{56}$ Consistently, the available evidence from the UK that uses compulsory schooling laws to estimate the effect of parental education on child health has not found significant effects (Lindeboom et al. 2009, Doyle et al. 2007).
} 
compulsory education laws tend to accompany curriculum changes, new buildings, and the hiring of new teachers. Any of these could have direct effects. Also, college openings may respond to educational demand in the local area. As a result, despite the often significant efforts of the researcher, the credibility of the estimates can always be called into question.

Even if the instrument is valid, the generalizability of the estimates is also an issue. Under monotonicity, among other assumptions, IV estimates provide the LATE (local average treatment effects); that is, the causal effect for those whose behavior is actually influenced by the instrument. For example, in the case of compulsory schooling laws, the estimated effects are for people whose behavior is influenced by the change in compulsory schooling legislation; i.e., those with low educational attainment. To the extent that the causal effect is different for this subgroup relative to the population as a whole, the results would not generalize.

\subsection{Reconciling Findings of Twins/Adoptees/IV Literatures}

It is troubling to note that, across methodologies (twins, adoptees, IV), estimates vary substantially. In recent work, Holmlund, Lindahl, and Plug (2008) set out to reconcile the findings, using all three methodologies and applying them to a single dataset from Sweden. In this way, they can disentangle whether differing estimates in the literature result from the different methodologies that have been used or from the different countries that have been studied. Importantly, they are able to replicate many of the results obtained by other researchers (for example, using twins they find father's education matters more than mother's; using a change in compulsory schooling as an 
instrument, they find the opposite), suggesting that the differing results are, at least in part, due to methodological differences rather than differences across countries. Regardless of methodology, however, they find that OLS significantly overstates the causal intergenerational relationship. A key point stressed by these authors is that the three different methods tend to shock different parts of the education distribution. While twins are fairly evenly distributed across the parental education distribution, adoptive families generally come from the higher end of the distribution. In contrast, changes in compulsory schooling laws mostly affect people with low educational levels. Therefore, in addition to other differences, results should be expected to vary across method if there are non-linearities in the intergenerational relationship.

Pronzato (2009) directly examines this issue using a twin fixed effects model. She uses a sample of Norwegian twins and evaluates the robustness of the estimates to restricting the sample to different parts of the parental education distribution. She finds that there is a strong positive effect of father's education on child education at the top end of the distribution but, at the bottom end, mother's education appears to matter more. These results are consistent with the idea that, by obtaining identification from different parts of the distribution, different methods should be expected to produce varying results.

In principle, the IV approach is preferable as it isolates the effect of an exogenous change in education of parents. Under the IV assumptions, parental education is as good as randomly assigned conditional on the covariates. The twins fixed effects approach can be seen as an IV approach that uses the within-pair difference in mother's education as the instrument for maternal education. It thus relies very heavily on the assumption that twin differences in education are random and uncorrelated with any other differences 
between the twins. The adoption approach differs in that it cannot isolate the effects of parental education from that of other correlated but unobserved parental characteristics. Despite the limitations associated with all three methods, however, we can still learn from their results.

Unfortunately, as can be seen in Table 3, taken as a whole the findings in the literature are very inconsistent. Some studies find OLS estimates that are larger than the causal effects but many find the opposite. Some studies find the effects of fathers' education to be greater; others find the effects of mothers to be more important. Clearly, there is a need for further work in this area.

\section{Section 3: Other Family Background Characteristics}

Recent research has moved beyond earnings and education to study a broad range of intergenerational relationships between other child and adult outcomes. We have chosen just a few to discuss below: ${ }^{57}$

\subsection{IQ/Ability}

There is a small but growing literature in economics on the intergenerational transmission of IQ. ${ }^{58}$ Recent data innovations, particularly in the Scandinavian countries, have enabled researchers to examine the correlations in IQ scores over time. Work by Black, Devereux and Salvanes (2009) uses Norwegian military data to examine the relationship between the IQ scores of fathers and sons, both measured at the age of 18 .

\footnotetext{
${ }^{57}$ There are large literatures in some of these areas and, by necessity, we have had to omit many interesting papers in this brief overview.

${ }_{58}$ Bouchard and McGue (1981) survey much of the non-economics literature.
} 
Using fathers who enrolled for conscription in the military in 1952 and 1953 and sons who enrolled between 1984 and 2005, we find that there is substantial intergenerational transmission of IQ scores; an increase in father's IQ of $10 \%$ is associated with a $3.2 \%$ increase in son's IQ score.

Bjorklund, Eriksson and Jantti (2010) use similar data from Sweden to extend this work, looking at both intergenerational and sibling correlations in IQ. They find a similar estimate of intergenerational correlation to that of Black, Devereux, and Salvanes. However, when they examine correlations between brothers, they find that close to half of the variation in IQ is accounted for by family and community background factors common to brothers, suggesting a more substantial role for families than might be suggested by the intergenerational correlation.

Anger and Heineck (2009) use data from the German Socio-Economic Panel Study to look at intergenerational correlations in cognitive skills for both men and women. They find estimates of intergenerational transmission that are larger than those found in the Scandinavian data. When they include mother's and father's IQ separately, they find slightly stronger effects of mother's IQ than father's. When they examine sons and daughters separately, they find evidence of an own-gender effect, with mothers influencing daughters more and fathers influencing sons.

Finally, Gronqvist, Ockert and Vlachos (2009) examine both cognitive and noncognitive intergenerational transmission using population-wide draft data in Sweden. Because the draft data are available only for men, they are limited to using predicted cognitive and non-cognitive ability measures for both mothers and fathers based on the enlistment evaluations of their brothers. They find a strong relationship between parents' 
ability and education and labor market outcomes of their children; parents' cognitive abilities matter more for educational outcomes while non-cognitive abilities matter more for earnings. Clearly, this is an area that will benefit from future research as more data become available.

This literature on IQ scores and cognitive skills is interesting as it moves us closer to understanding what exactly is handed down by parents to their children. However, given that cognitive skills are influenced by both genetic and environmental factors and are correlated with many other family background characteristics, no clear causal mechanisms have been uncovered by this literature.

\subsection{Jobs and Occupations}

Several studies examine intergenerational mobility in occupation and find strong correlations between fathers and sons. Hellerstein and Morrill (2008) show that, in recent cohorts, about $30 \%$ of sons and $20 \%$ of daughters work in the same occupation as their father. However, these percentages are sensitive to how finely occupation is defined. ${ }^{59}$ For this reason, many studies create some metric of occupational rank or prestige and correlate this more continuous measure of parent and child occupation. Using this type of approach, Ermish and Francesconi (2002) find intergenerational correlations that range from 0.4 to 0.75 for father-child pairs and from 0.30 to 0.50 for mother-child pairs in the British Household Panel Survey. They find that the effects are nonlinear, with a higher elasticity for higher socio-economic status parents. They also find that more recent cohorts are more mobile than their earlier counterparts. Using slightly different methods,

\footnotetext{
${ }^{59}$ The focus of this paper is on disentangling the reasons for the increase over time in the proportion of daughters in the same occupation as their father.
} 
Carmichael (2000), using the BHPS, and Di Pietro and Urwin (2003), using Italian data, find strong relationships between father and son occupations. ${ }^{60}$ Ferrie (2005) demonstrates that occupational mobility in the U.S. was much greater in the late 19th century than in the 20th century.

A few recent studies have moved beyond occupation to see if children get jobs in the same firms as their parents. Using Canadian data, Corak and Piraino (2010) show that, by their early 30 s, about $40 \%$ of men have worked with an employer that had also employed their father at some point in time. Interestingly, they find that this occurs more frequently when fathers are higher earners. This finding is consistent with other research showing that family based succession is common in large companies - incoming CEOs are often the sons or daughters of departing CEOs or large shareholders. See PérezGonzález (2006) for evidence from the United States, and Bennedsen et al. (2007) for Danish evidence.

Using Swedish register data, Kramarz and Skans (2007) show that boys are much more likely than their classmates to get their first stable job in the plant in which their father works. The corollary is that plants are more likely to hire a boy if his father works there. They show that while this applies most to low-educated children, fathers tend to provide access to relatively high wage plants. Symmetrically, they find that girls are more likely than their classmates to get jobs in plants in which their mother works. These findings suggest that there may be a causal effect of the jobs parents hold on their children's labor market outcomes. Further work in this area might be useful to sort out the relative roles of discrimination, preference transmission, and information.

\footnotetext{
${ }^{60}$ It is also well established that children are more likely to become self-employed if a parent is selfemployed. See, for example, Dunn and Holtz-Eakin (2000).
} 


\subsection{Welfare Receipt}

There is also a literature focusing on the intergenerational transmission of welfare receipt. A preponderance of the evidence suggests a strong intergenerational correlation in welfare participation. ${ }^{61}$ However, there is little evidence on the causal relationship. As Levine and Zimmerman (1996) describe, it is important, from a policy perspective, to distinguish between a poverty trap and a welfare trap. A poverty trap arises from the intergenerational correlation of income; because welfare receipt is means-tested, families with low-income parents, who are thus more likely to be welfare recipients, are more likely to have low-income children, who will also be more likely to qualify for welfare. Note that, in this case, the higher incidence of welfare receipt among the children of welfare recipients is due solely to the means-tested nature of welfare combined with the intergenerational correlation in income.

Of more concern from a policy perspective may be the notion of the welfare trap; in this case, it is not the mechanical nature of the means-tested policy that leads to the correlation between parents and children but instead some feature of the program itself. An example of this would be that children who grew up on welfare believe it is more socially acceptable to be on welfare and, as a result, for a given level of earnings as an adult, may be more likely to enroll in welfare.

It is quite difficult to distinguish between these two types of intergenerational persistence. Despite this, Levine and Zimmerman (1996) apply a number of different approaches to distinguish the poverty trap from the welfare trap, including 1. comparing actual participation of children to that predicted based on parents' income and 2. using

\footnotetext{
${ }^{61}$ See work by Page (2004).
} 
variation in welfare generosity across states. They conclude that most of the persistence in welfare use across generations is because of the poverty trap; at least three quarters (and possibly all) of the correlation can be attributed to the expected intergenerational correlation in income and other family characteristics, leaving little if any room for a welfare trap argument. ${ }^{62}$

A number of other studies focus on the intensity of exposure among children who were all exposed to welfare as a child to examine whether or not variation in the intensity of exposure leads to variation in later welfare receipt as adults. Among these are papers by Beaulieu et al. (2005) using Canadian administrative data and Mitnik (2008) using administrative data from California. The two papers use different econometric approaches and come to very different conclusions; using a structural approach, Beaulieu et al. find that increased welfare use by parents leads to increased use by children, while Mitnik, using sibling differences in exposure, finds no effect of length of exposure on future welfare dependency. Overall, while the intergenerational correlations in welfare receipt are clear, there is much less evidence that a causal relationship exists.

\subsection{Health}

Intergenerational transmission of health has also been a focus of recent research. A number of papers have established a positive intergenerational correlation in a variety of health outcomes. A recent study by Coneus and Spieß, (2008) uses the German SocioEconomic Panel and various anthropometric (i.e. weight, height, BMI) and self-reported health measures and finds intergenerational transmission of health between parents and

\footnotetext{
${ }^{62}$ Pepper (2000) considers the incidence and intensity of welfare enrollment. Using data from the PSID and a nonparametric bounding method to examine the effect, he finds evidence that being on welfare as a child increases both the probability and expected duration of future welfare use.
} 
children younger than four years old. Akbulut and Kugler (2007) use the NLSY79 to examine correlations in height, weight, BMI, depression, and asthma in the U.S. They find that children inherit a substantial proportion of their health (anthropometric and emotional) from their mothers. Loureiro et al. (2006) examine intergenerational transmission of smoking habits using the BHPS (1994-2002) and find 18 year olds are about twice as likely to smoke if both parents smoke than if neither parent smokes. ${ }^{63}$

Fewer papers have actually tried to identify a causal link, and those that have focus on intergenerational transmission of birth weight. As with all the work in this literature, a key issue with establishing causation is whether other family characteristics (such as poverty) affect the birth weight of both the parent and the child. If this is the case, despite an observed correlation between parent and child birth weight, there may be no causal relationship. Currie and Moretti (2007) address this issue by comparing mothers who are siblings, thereby differencing out fixed family characteristics. Using data from individual birth records from California, they find that the probability that a child is low birth weight is almost $50 \%$ higher if the mother herself had low birth weight, even after controlling for a family fixed effect. They estimate an intergenerational low birth weight elasticity of 0.2 , suggesting strong intergenerational correlations between mothers' and children's birth weight. ${ }^{64}$

Other work has looked within twin pairs of mothers. Differences in birth weight within twin pairs are unrelated to family characteristics (as both twins have the same environment) and, among identical twins, there are no genetic differences either. Black, Devereux, and Salvanes (2007) use data from Norway and find elasticity estimates of

\footnotetext{
${ }^{63}$ Intergenerational transmission of health is an important issue in developing countries. See Bhalotra and Rawlings (2009) for a recent analysis.

${ }^{64}$ They also show that this effect is stronger for women living in poorer neighborhoods.
} 
approximately .18 for a sample of twin mothers; these estimates are relatively insensitive to the inclusion of twin fixed effects. ${ }^{65}$ We also find an elasticity of .18 using twin fixed effects when the sample is restricted to monozygotic twin mothers. Royer (2009), using data from California, also finds positive but smaller effects using twin fixed effects. ${ }^{66}$

\footnotetext{
${ }^{65}$ Note that we estimate an OLS elasticity of .25 on the sample of all siblings in the data; this estimate declines to .13 when we include sibling fixed effects.

${ }^{66}$ Currie and Hyson (1999) show that, while socioeconomic status does not mitigate the effects of low birth weight on economic outcomes of children, it does offset the effect of low birth weight on female health status.
} 


\subsection{Attitudes and Social Behavior}

There is also a recent literature examining the intergenerational transmission of attitudes and social behaviors. It is very difficult to estimate causal effects with these types of variables, so the literature is predominantly based on correlations. Altonji and Dunn (2000) use panel data from the NLS to study intergenerational persistence in wages and work preferences and argue positive intergenerational correlations in work hours are primarily due to preferences. Mayer et al. (2005) use the NLSY and find strong correlations between mothers' and daughters' traits, behavior and attitudes; only a small fraction of this correlation is explained by family socioeconomic status, suggesting that it may be the attitudes themselves that matter. Wilhelm et al. (2008) use the PSID to examine intergenerational transmission in charitable donations and separately study secular giving and religious giving. They find that the religious elasticity is larger than the secular elasticity, with estimates ranging from 0.26 to 0.31 for religious giving and from 0.08 to 0.14 for secular giving. Using the German Socio-Economic Panel (SOEP), Dohmen et al. (2008) show that willingness to take risks and levels of trust are correlated across generations.

Almond, Edlund, and Milligan (2009) argue that there is persistence of culture across generations. To test this, they study Asian immigrants to Canada. Because these immigrants are neither poor nor in a society that tolerates sex selection, the fact that they observe son preferences (boy-girl ratios that rise with parity if there is no previous son) suggests that these preferences for sons are transmitted intergenerationally. To further 
validate these results, they also show significant differences across religious affiliations that coincide with historical differences in beliefs about infanticide. ${ }^{67}$

The preponderance of research in this area has focused on correlations across generations. The exception to this, however, is work by Fernandez, Fogli, and Olivetti (2004), who argue that the behavior of the mother has a causal influence on the preferences of the son in terms of the marriage market. Using geographic variation in the importance of World War II as a shock to women's labor force participation, they find that if a mother works this has a positive causal effect on the probability that the son's wife works. This suggests that the increasing number of men brought up in a family in which the mother worked may have been a significant factor in the increase in female labor force participation over time. Given the growing focus on culture and political economy in research more generally, this is clearly an interesting area for future research.

\subsection{Consumption and Wealth}

There are other papers that attempt to determine intergenerational persistence of economic outcomes by looking at consumption or wealth instead of income. An example of this is work by Waldkirch, Ng, and Cox (2004), which looks at consumption using information about parents and their children from the Panel Study of Income Dynamics (PSID). Raw estimates suggest intergenerational correlations in food consumed away from home (one measure of consumption) in the range of .14-.20. The authors then attempt to distinguish how much of this is due to differences in income relative to

\footnotetext{
${ }^{67}$ For example, Sikhs have the highest sex ratios, while Christian or Muslim Asians have the lowest, suggesting that explicit prohibition of post-birth sex selection may also be protecting unborn girls against prenatal sex selection.
} 
differences in taste and conclude that both parental income and tastes have statistically significant effects on consumption of their children.

In addition, work by Charles and Hurst (2003) uses data on wealth from the Panel Study of Income Dynamics to estimate the intergenerational wealth elasticity. When they regress log of child's wealth on the log of parent's wealth, controlling for child and parental age, they find an intergenerational wealth elasticity of 0.37 , higher than that suggested by previous studies. They also show that twenty percent of parents in the lowest quintile of the parent's wealth distribution have children who move to the top two quintiles of the child's wealth distribution. Similarly, one-quarter of the parents in the highest wealth quintile also have children who end up in the lowest two quintiles of the child's wealth distribution. ${ }^{68}$ It is interesting that the intergenerational wealth elasticity appears to be lower than the IGE and further work on the relationships between them may be valuable.

\section{Section 4: Conclusion}

The literature on intergenerational mobility has witnessed great progress over the last decade. To understand the advances we have made, we went back to Solon's (1999) chapter to see whether his suggestions for future research actually came to fruition, and, indeed, a number of his suggestions have developed into active areas of research.

Solon suggested that we "study how the sibling resemblance in earnings varies across different sibling types known to vary in the extent to which they share genes and environments." (page 1776). Thanks to registry data from the Nordic countries, we have

${ }^{68}$ Using data from France, Arrondel (2009) reports an elasticity of children's wealth with respect to that of their parents of around 0.22 . 
made significant progress in this direction. Creative use of adoptees and different sibling types has provided compelling evidence that both nature and nurture are important for child outcomes. The work by Bjorklund et al. (2005) is at the forefront of this literature, and it is clear that we will continue to make progress as better data, including data on the underlying genetic structure of individuals, become available. An important avenue for future research is further work on gene-environment interactions and how they mediate the effects of policy interventions.

Solon also noted, "Now that we know parental income is a fairly strong predictor of offspring's earnings, it becomes that much more important to find out which of the causal processes... are mainly responsible for the empirically observed intergenerational associations of earnings." (page 1789). This, too, proved to be portentous; perhaps the most significant recent progress in the literature has been on causal processes. Work using adoptees, twins, and instrumental variables strategies has allowed us to make significant advances in our understanding of why we observe these correlations.

We have also learned something about what types of policy changes can lead to reductions in intergenerational persistence. Some of the Nordic evidence suggests that intergenerational persistence can be heavily influenced by education policy reforms that extend the length of compulsory education and delay tracking. Interestingly, work on these reforms also suggests that the positive impacts on people from less-educated backgrounds spillover to the next generation to only a limited extent. We hope there will be further work linking policy changes directly to changes in intergenerational relationships. 
While intergenerational mobility has been an active area of research, there is still a lot that we cannot currently explain, and there is much room for research in this area in the future. Recent high quality estimates of IGEs and sibling correlations suggest that family background is very important in the U.S. but much less so in the Nordic countries. Research in both the U.S. and Norway suggests that neighborhood is not the prime determinant. However, there is still much work to do to pin down which family background factors are most important.

Additionally, despite a decade of progress, we have a wide range of findings about whether it is mother's or father's education that matters more for offspring and quite limited evidence on the causal effect of family income. There is scope for much more research on these core topics. And, clearly, as we continue to study topics such as the intergenerational transmission of health, weight, behavior, and preferences, the reach of this literature will continue to grow. 
Table 1

Elasticity and Correlations from Jantti et al. [2006]

This reproduces much of Jantti et al. [2006] Table 2. Numbers in brackets below the point estimates show the bias corrected 95 percent bootstrap confidence interval.

\begin{tabular}{|c|c|c|}
\hline Country & Elasticity & Correlation \\
\hline \multicolumn{3}{|l|}{ MEN } \\
\hline \multirow[t]{2}{*}{ Denmark } & 0.071 & 0.089 \\
\hline & {$[0.064,0.079]$} & {$[0.079,0.099]$} \\
\hline \multirow[t]{2}{*}{ Finland } & 0.173 & 0.157 \\
\hline & {$[0.135,0.211]$} & {$[0.128,0.186]$} \\
\hline \multirow[t]{2}{*}{ Norway } & 0.155 & 0.138 \\
\hline & {$[0.137,0.174]$} & {$[0.123,0.152]$} \\
\hline \multirow[t]{2}{*}{ Sweden } & 0.258 & 0.141 \\
\hline & {$[0.234,0.281]$} & {$[0.129,0.152]$} \\
\hline \multirow[t]{2}{*}{ U.K. } & 0.306 & 0.198 \\
\hline & {$[0.242,0.370]$} & {$[0.156,0.240]$} \\
\hline \multirow[t]{2}{*}{ U.S. } & 0.517 & 0.357 \\
\hline & {$[0.444,0.590]$} & {$[0.306,0.409]$} \\
\hline \multicolumn{3}{|l|}{ WOMEN } \\
\hline \multirow[t]{2}{*}{ Denmark } & 0.034 & 0.045 \\
\hline & {$[0.027,0.041]$} & {$[0.036,0.054]$} \\
\hline \multirow[t]{2}{*}{ Finland } & 0.080 & 0.074 \\
\hline & {$[0.042,0.118]$} & {$[0.045,0.103]$} \\
\hline \multirow[t]{2}{*}{ Norway } & 0.114 & 0.084 \\
\hline & {$[0.090,0.137]$} & {$[0.070,0.099]$} \\
\hline \multirow[t]{2}{*}{ Sweden } & 0.191 & 0.102 \\
\hline & {$[0.166,0.216]$} & {$[0.090,0.113]$} \\
\hline \multirow[t]{2}{*}{ U.K. } & 0.331 & 0.141 \\
\hline & {$[0.223,0.440]$} & {$[0.099,0.183]$} \\
\hline \multirow[t]{2}{*}{ U.S. } & 0.283 & 0.160 \\
\hline & {$[0.181,0.385]$} & {$[0.105,0.215]$} \\
\hline
\end{tabular}


Table 2

\section{Countries Ranked by Average Parent-Child Schooling Correlation}

\section{from Hertz et al. [2007]}

Individuals Aged 20-69

This reproduces most of Hertz et al. [2007] Table 2.

\begin{tabular}{|c|c|c|c|c|}
\hline Country & Coefficient & Rank & Correlation & Rank \\
\hline Peru & 0.88 & 6 & 0.66 & 1 \\
\hline Ecuador & 0.72 & 12 & 0.61 & 2 \\
\hline Panama & 0.73 & 11 & 0.61 & 3 \\
\hline Chile & 0.64 & 18 & 0.60 & 4 \\
\hline Brazil & 0.95 & 4 & 0.59 & 5 \\
\hline Colombia & 0.80 & 8 & 0.59 & 6 \\
\hline Nicaragua & 0.82 & 7 & 0.55 & 7 \\
\hline Indonesia & 0.78 & 9 & 0.55 & 8 \\
\hline Italy $\dagger$ & 0.67 & 17 & 0.54 & 9 \\
\hline Slovenia $\uparrow$ & 0.54 & 27 & 0.52 & 10 \\
\hline Egypt & 1.03 & 2 & 0.50 & 11 \\
\hline Hungary $\dagger$ & 0.61 & 20 & 0.49 & 12 \\
\hline Sri Lanka & 0.61 & 19 & 0.48 & 13 \\
\hline Pakistan & 1.00 & 3 & 0.46 & 14 \\
\hline USA & 0.46 & 33 & 0.46 & 15 \\
\hline Switzerland $\uparrow$ & 0.49 & 30 & 0.46 & 16 \\
\hline Ireland $\dagger$ & 0.70 & 15 & 0.46 & 17 \\
\hline South Africa (KwaZulu-Natal) & 0.69 & 16 & 0.44 & 18 \\
\hline Poland $\uparrow$ & 0.48 & 31 & 0.43 & 19 \\
\hline Vietnam & 0.58 & 23 & 0.40 & 20 \\
\hline Philippines & 0.41 & 36 & 0.40 & 21 \\
\hline Belgium (Flanders) & 0.41 & 35 & 0.40 & 22 \\
\hline Estonia & 0.54 & 28 & 0.40 & 23 \\
\hline Sweden & 0.58 & 26 & 0.40 & 24 \\
\hline Ghana & 0.71 & 13 & 0.39 & 25 \\
\hline Ukraine & 0.37 & 40 & 0.39 & 26 \\
\hline East Timor & 1.27 & 1 & 0.39 & 27 \\
\hline Bangladesh (Matlab) & 0.58 & 25 & 0.38 & 28 \\
\hline Slovakia & 0.61 & 21 & 0.37 & 29 \\
\hline Czech Republic $\dagger$ & 0.44 & 34 & 0.37 & 30 \\
\hline The Netherlands & 0.58 & 24 & 0.36 & 31 \\
\hline Norway & 0.40 & 38 & 0.35 & 32 \\
\hline Nepal & 0.94 & 5 & 0.35 & 33 \\
\hline New Zealand $\dagger$ & 0.40 & 37 & 0.33 & 34 \\
\hline Finland & 0.48 & 32 & 0.33 & 35 \\
\hline Northern Ireland & 0.59 & 22 & 0.32 & 36 \\
\hline Great Britain $\uparrow$ & 0.71 & 14 & 0.31 & 37 \\
\hline Malaysia & 0.38 & 39 & 0.31 & 38 \\
\hline Denmark & 0.49 & 29 & 0.30 & 39 \\
\hline Kyrgyzstan & 0.20 & 42 & 0.28 & 40 \\
\hline China(Rural) & 0.34 & 41 & 0.20 & 41 \\
\hline Ethiopia(Rural) & 0.75 & 10 & 0.10 & 42 \\
\hline
\end{tabular}

Surveyed between 1994 and 2004, except Peru (1985), Malaysia (1988) and Pakistan (1991).

$\dagger$ Ages 20 to 64 or 65 only. 
Table 3

Causal estimates of intergenerational effects of schooling - Summary of previous literature From Holmlund, Lindahl, and Plug [2008], Table 1

\begin{tabular}{|c|c|c|c|c|c|c|c|}
\hline \multirow[t]{4}{*}{ Author } & \multirow[t]{4}{*}{ Sample characteristics } & \multirow[t]{4}{*}{$\begin{array}{l}\text { Child's } \\
\text { outcome }\end{array}$} & \multirow[t]{4}{*}{$\begin{array}{l}\text { Assort. } \\
\text { mating }^{\mathrm{c}}\end{array}$} & & & & \\
\hline & & & & \multicolumn{2}{|c|}{ OLS estimates } & \multicolumn{2}{|c|}{ Difference estimates } \\
\hline & & & & $\begin{array}{l}\text { Father } \\
\text { (1) }\end{array}$ & $\begin{array}{l}\text { Mother } \\
\text { (2) }\end{array}$ & $\begin{array}{l}\text { Father } \\
\text { (3) }\end{array}$ & $\begin{array}{l}\text { Mother } \\
\text { (4) }\end{array}$ \\
\hline & & & & & & & \\
\hline \multirow{4}{*}{$\begin{array}{l}\text { Behrman } \\
\text { Rosenzweig } \\
(2002)\end{array}$} & MTR $^{\mathrm{a}}, 1994: 244$ twin & Years of & (no) & $0.47^{\mathrm{b}}$ & 0.33 & 0.36 & -0.25 \\
\hline & $\begin{array}{l}\text { fathers and } 424 \text { twin } \\
\text { mothers; average birth year }\end{array}$ & schooling & & $0.05^{* *}$ & $0.05 * *$ & $0.16^{* *}$ & 0.15 \\
\hline & parent 1947; sample 1947 & & (yes) & 0.33 & 0.14 & 0.34 & -0.27 \\
\hline & and 1971. & & & $0.07 * *$ & $0.05 * *$ & $0.16^{* *}$ & 0.15 \\
\hline \multirow{4}{*}{$\begin{array}{l}\text { Antonovics } \\
\text { Goldberger } \\
(2005)\end{array}$} & MTR, 1994: 92 twin fathers & Years of & (no) & 0.49 & 0.28 & 0.48 & 0.03 \\
\hline & & schooling & & $0.09 * *$ & $0.09 * *$ & 0.16 & 0.27 \\
\hline & of 18 and older, not in & & (yes) & 0.50 & 0.10 & 0.48 & -0.003 \\
\hline & school. & & & NA & NA & NA & NA \\
\hline \multirow{4}{*}{$\begin{array}{l}\text { Bingley } \\
\text { Christensen } \\
\text { Myrup Jensen } \\
\text { (2009) }\end{array}$} & DAR, 2004: 2713 twin & Years of & (no) & 0.18 & 0.18 & 0.08 & 0.05 \\
\hline & fathers and 2975 twin & schooling & & $(0.01)^{* *}$ & $(0.01)^{* *}$ & $(0.03)^{* *}$ & $(0.03)$ \\
\hline & $\begin{array}{l}\text { mothers, children born 1956- } \\
1979 \text { children aged } 25 \text { or }\end{array}$ & & & & & & \\
\hline & $\begin{array}{l}\text { 1979, children aged } 25 \text { or } \\
\text { older in } 2004 .\end{array}$ & & (yes) & $\begin{array}{c}0.12 \\
(0.01)^{* *}\end{array}$ & $\begin{array}{c}0.14 \\
(0.01)^{* *}\end{array}$ & $\begin{array}{c}0.07 \\
(0.03)^{* *}\end{array}$ & $\begin{array}{c}0.03 \\
(0.02)\end{array}$ \\
\hline \multirow[t]{2}{*}{$\begin{array}{l}\text { Pronzato } \\
(2009)\end{array}$} & $\begin{array}{l}\text { NAR, 2001, } 1606 \text { twin } \\
\text { fathers and } 1609 \text { twin }\end{array}$ & $\begin{array}{l}\text { Years of } \\
\text { schooling }\end{array}$ & (no) & & & & \\
\hline & $\begin{array}{l}\text { mothers, children aged } 23 \text { or } \\
\text { older in } 2001 .\end{array}$ & & (yes) & $\begin{array}{c}0.21 \\
(0.02)^{* *}\end{array}$ & $\begin{array}{c}0.24 \\
(0.02)^{* *}\end{array}$ & $\begin{array}{c}0.16 \\
(0.03)^{* *}\end{array}$ & $\begin{array}{c}0.10 \\
(0.04)^{*}\end{array}$ \\
\hline \multirow{3}{*}{$\begin{array}{l}\text { Holmlund } \\
\text { Lindahl } \\
\text { Plug } \\
\text { (2008) }\end{array}$} & $\begin{array}{l}\text { SAR, parents born } 1943-55 \text {, } \\
5866 \text { twin mothers and } 4061\end{array}$ & $\begin{array}{l}\text { Years of } \\
\text { schooling }\end{array}$ & (no) & $\begin{array}{c}.21 \\
(.01)^{* *}\end{array}$ & $\begin{array}{c}.25 \\
(.01)^{* *}\end{array}$ & $\begin{array}{c}.12 \\
(.03)^{* *}\end{array}$ & $\begin{array}{c}.06 \\
(.03) *\end{array}$ \\
\hline & twin fathers. & & & & & & \\
\hline & & & (yes) & .15 & .18 & .11 & .04 \\
\hline
\end{tabular}


Sacerdote (2000)

NLSY, 1979: 5614 own birth Years of and 170 adopted children. Average birth year child: 1961

schooling

Plug (2004) WLS, 1992: 15871 own

birth and 610 adopted

children. Birth year mother:

1940, average birth year

adopted and birth child:

1969 and 1965.

Sacerdote HICS, 2003: 1051 own birth Years of (2007)

and 1256 adopted children

from Korea. Average birth

year adopted and birth child: 1975 and 1969.

Björklund SAR, 1999: 94079 own birth Years of

Lindahl

Plug (2006)

and 2125 adopted children

all born in Sweden; average

birth year mother: 1932;

average birth year child:

1964.

Holmlund

Lindahl

Plug

(2008)

Years of

schooling

schooling

schooling

schooling (no)

$\begin{array}{cc}0.28 & 0.35 \\ 0.01 * * & 0.01 * *\end{array}$

(yes)

(no)

0.39

0.54

(yes)

$0.01 * *$

.02

0.30

0.30
$0.02 * *$

(no)

0.32

$0.03 * *$

(no)

0.24

$0.00 * *$

0.24

$0.00 * *$

0.11

0.07

(yes)

0.17

0.16

$0.00 * *$

$0.00^{* *}$

0.01 **

(no)

0.23

0.28

0.23

$0.00 * *$

(yes)

0.15

$0.00^{* *}$

$0.20 * *$

$0.00^{* *}$

0.09

0.02

$0.01 * *$

0.04

0.04

0.01 **

$0.01 * *$

0.03
$0.01 *$

0.03
$0.01 * *$

$0.01^{*} \quad 0.01 * *$ 


\begin{tabular}{|c|c|c|c|c|c|c|c|}
\hline $\begin{array}{l}\text { Black } \\
\text { Devereux } \\
\text { Salvanes } \\
(2005)\end{array}$ & $\begin{array}{l}\text { NAR, 2000: } 239854 / 172671 \\
\text { children 1965-75; birth year } \\
\text { parent: } 1947-58 \text {; instrument } \\
\text { MSLA reform in 1960-1972. }\end{array}$ & $\begin{array}{c}\text { Years of } \\
\text { schooling }\end{array}$ & $\begin{array}{l}\text { (no) } \\
\text { (no) }\end{array}$ & $\begin{array}{c}0.22 \\
0.003^{* *} \\
0.21 \\
0.02 * *\end{array}$ & $\begin{array}{c}0.24 \\
0.003 * * \\
0.21 \\
0.02 * *\end{array}$ & $\begin{array}{l}0.03 \\
0.13 \\
0.04 \\
0.06\end{array}$ & $\begin{array}{c}0.08 \\
0.14 \\
\\
0.12 \\
0.04^{* *}\end{array}$ \\
\hline $\begin{array}{l}\text { Chevalier } \\
(2004)\end{array}$ & $\begin{array}{l}\text { BFRS 1994-2002: } 12593 \\
\text { children aged 16-18 living at } \\
\text { home; birth year parent: } \\
\text { 1938-67; instrument MSLA } \\
\text { reform in } 1972 .\end{array}$ & $\begin{array}{l}\text { Post- } \\
\text { compuls. } \\
\text { school } \\
\text { attend. }\end{array}$ & (yes) & $\begin{array}{l}0.04^{\mathrm{c}, \mathrm{d}} \\
0.00^{* *}\end{array}$ & $\begin{array}{l}0.04^{\mathrm{c}, \mathrm{d}} \\
0.00^{* *}\end{array}$ & $\begin{array}{c}-0.01^{\mathrm{c}, \mathrm{d}} \\
0.06^{* *}\end{array}$ & $\begin{array}{l}0.11^{\mathrm{c}, \mathrm{d}} \\
0.04^{* *}\end{array}$ \\
\hline $\begin{array}{l}\text { Oreopoulos } \\
\text { Page } \\
\text { Stevens }(2003, \\
2006)\end{array}$ & $\begin{array}{l}\text { IPUMS 1960-80: } 711072 \\
\text { children aged 7-15 living at } \\
\text { home; average birth year } \\
\text { father and child: } 1920-40 \\
\text { and 1950-70; instrument: } \\
\text { MSLA reforms between } \\
\text { 1915-70. }\end{array}$ & $\begin{array}{l}\text { Grade } \\
\text { repetition } \\
\text { (actual- } \\
\text { normal) }\end{array}$ & $\begin{array}{l}\text { (no) } \\
\text { (no) }\end{array}$ & $\begin{array}{c}-0.03 \\
0.00^{* *} \\
-0.04 \\
0.00^{* *}\end{array}$ & $\begin{array}{l}-0.04 \\
0.00^{* *} \\
-0.04 \\
0.00^{* *}\end{array}$ & $\begin{array}{c}-0.06 \\
0.01^{* *} \\
-0.07 \\
0.01^{* *}\end{array}$ & $\begin{array}{c}-0.05 \\
0.01^{* *} \\
-0.06 \\
0.01^{* *}\end{array}$ \\
\hline $\begin{array}{l}\text { Maurin } \\
\text { McNally } \\
(2008)\end{array}$ & $\begin{array}{l}\text { FLFS 1990-2001: } 5087 \\
\text { children aged } 15 \text { and living } \\
\text { at home; birth year father } \\
\text { 1946-52; instrument: } \\
\text { university reform in } 1968 \text {. }\end{array}$ & $\begin{array}{l}\text { Grade } \\
\text { repetition } \\
\text { (actual- } \\
\text { normal) }\end{array}$ & (no) & $\begin{array}{c}-0.08 \\
0.00^{* *}\end{array}$ & & $\begin{array}{c}-0.33 \\
0.12 * *\end{array}$ & \\
\hline $\begin{array}{l}\text { Carneiro } \\
\text { Meghir } \\
\text { Parey (2007) }\end{array}$ & $\begin{array}{l}\text { NLSY, 1979: } 1958 \text { white } \\
\text { children aged 12-14; } \\
\text { instruments: local tuition } \\
\text { fees, unemployment rates } \\
\text { and wages. }\end{array}$ & $\begin{array}{l}\text { Grade } \\
\text { repetition } \\
\text { (actual- } \\
\text { normal) }\end{array}$ & (no) & & $\begin{array}{c}-0.023 \\
0.005^{* *}\end{array}$ & & $\begin{array}{l}-0.028 \\
0.011^{*}\end{array}$ \\
\hline $\begin{array}{l}\text { Holmlund } \\
\text { Lindahl } \\
\text { Plug } \\
(2008)\end{array}$ & $\begin{array}{l}\text { SAR, parents born } 1943-55 \text {, } \\
5866 \text { twin mothers and } 4061 \\
\text { twin fathers. }\end{array}$ & $\begin{array}{l}\text { Years of } \\
\text { schooling }\end{array}$ & $\begin{array}{l}\text { (no) } \\
\text { (yes) }\end{array}$ & $\begin{array}{c}0.22 \\
0.01 * *\end{array}$ & $\begin{array}{c}0.28 \\
0.01^{* *}\end{array}$ & $\begin{array}{c}-0.07 \\
0.10\end{array}$ & $\begin{array}{l}0.11 \\
0.06\end{array}$ \\
\hline
\end{tabular}


Administrative Records; BFRS - British Family Resources Survey; IPUMS - Integrated Public Microdata Series; FLFS - French Labor Force Survey; MSLA - Minimum School Leaving Age.

${ }^{\mathrm{b}}$ Standard errors in italics; ${ }^{* *}$ significant at $1 \%$ level; * significant at 5\% level. Each coefficient is from a separate regression of the child's outcome on parent's years of schooling. Most regressions include individual controls for the child's age and gender and parent's age.

${ }^{\mathrm{c}}$ When yes, these coefficients come from regressions that include the years of schooling of both parents simultaneously. Resulting estimates take into account the intergenerational effect of the marriage partner.

${ }^{\mathrm{d}}$ These coefficients come from probit regressions.

${ }^{\mathrm{e}}$ These coefficients come from a restricted sample of parents with less than 10 (12) years of schooling in Norway (The United States) 
Table 4

Transmission Coefficients from Björklund, Lindahl, Plug [2006]

(1)

(2)
(3)

(4)
(5)

(6)

\section{Years of Years of University University Earnings Income Schooling Schooling (4 years) (4 years)}

\begin{tabular}{|c|c|c|c|c|c|c|}
\hline \multicolumn{7}{|l|}{ Non Adoptees } \\
\hline Biological father & $\begin{array}{l}.240 * * \\
(0.002)\end{array}$ & & $\begin{array}{l}.339 * * \\
(0.004)\end{array}$ & & $\begin{array}{l}.235 * * \\
(0.005)\end{array}$ & $\begin{array}{l}.241 * * \\
(0.004)\end{array}$ \\
\hline Biological mother & & $\begin{array}{c}.243 * * \\
(0.002)\end{array}$ & & $\begin{array}{c}.337 * * \\
(0.004)\end{array}$ & & \\
\hline \multicolumn{7}{|l|}{ Adoptees } \\
\hline Biological father & $\begin{array}{l}.113 * * \\
(0.016)\end{array}$ & & $\begin{array}{l}.184 * * \\
(0.036)\end{array}$ & & $\begin{array}{r}0.047 \\
(0.034)\end{array}$ & $\begin{array}{r}.059 * \\
(0.028)\end{array}$ \\
\hline Biological mother & & $\begin{array}{l}.132 * * \\
(0.017)\end{array}$ & & $\begin{array}{c}.261 * * \\
(0.034)\end{array}$ & & \\
\hline Adoptive father & $\begin{array}{l}.114 * * \\
(0.013)\end{array}$ & & $\begin{array}{c}.165 * * \\
(0.024)\end{array}$ & & $\begin{array}{c}.098 * * \\
(0.038)\end{array}$ & $\begin{array}{l}.172 * * \\
(0.031)\end{array}$ \\
\hline Adoptive mother & & $\begin{array}{c}.074 * * \\
(0.014)\end{array}$ & & $\begin{array}{l}.145^{* *} \\
(0.024)\end{array}$ & & \\
\hline $\begin{array}{l}\text { Sum of estimates for } \\
\text { biological and adoptive } \\
\text { Fathers }\end{array}$ & $\begin{array}{l}.227 * * \\
(0.019)\end{array}$ & & $\begin{array}{c}.349 * * \\
(0.040)\end{array}$ & & $\begin{array}{c}.145 * * \\
(0.049)\end{array}$ & $\begin{array}{l}.231 * * \\
(0.040)\end{array}$ \\
\hline $\begin{array}{l}\text { Sum of estimates for } \\
\text { biological and adoptive } \\
\text { mothers }\end{array}$ & & $\begin{array}{c}.207 * * \\
(0.021)\end{array}$ & & $\begin{array}{c}.406 * * \\
(0.039)\end{array}$ & & \\
\hline
\end{tabular}

This reproduces BLP [2006] Table II. Each coefficient is from a separate regression of child's outcome on parents outcomes. Standard errors are shown in parentheses; * indicates significance at 5 percent level, and ** at 1 percent level. Data are from the Swedish National Registry. All specifications include controls for the child's gender, 4 birth cohort dummies for the child, 8 birth cohort dummies for biological/adoptive father/mother, and 25 region dummies for where the biological/adoptive family lived in 1965. The numbers of observations in the second panel for own-birth and adopted children are 94,079/2,125 in columns (1)(4), 87,079/1,780 in column (5) and 91,932/1,976 in column (6). 


\section{References}

Akbulut, Mevlude and Adriana D. Kugler (2007), "Inter-generational transmission of health status in the U.S among natives and immigrants", Mimeo (University of Houston).

Almond, Douglas, Lena Edlund, Kevin Milligan (2009), "Son preference and the persistence of culture: evidence from Asian immigrants to Canada", Working paper no. 15391 (NBER, Cambridge, MA).

Almond, Douglas and Janet Currie (this volume) "Human Capital Development Before Age 5."

Altonji, Joseph G. and Thomas A. Dunn (2000), “An intergenerational model of wages, hours, and earnings", Journal of Human Resources 35: 221-258.

Anger, Silke and Guido Heineck (2009), "Do Smart Parents raise smart children? The intergenerational transmission of cognitive abilities", Working paper no. 156 (SOEP, DIW, Berlin).

Antonovics, Kate and Arthur S. Goldberger (2005), "Does increasing women's schooling raise the schooling of the next generation? Comment", American Economic Review 95: 1738-1744.

Arrondel, Luc (2009), "My Father Was Right: The transmission of values between generations," PSE Working Papers 2009-12.

Baker, Michael, and Gary Solon (2003), "Earnings dynamics and inequality among Canadian men, 1976-1992”, Journal of Labor Economics 21: 289-321.

Bauer, Philipp C. and Regina T. Riphahn (2006), "Timing of school tracking as a determinant of intergenerational transmission of education", Economics Letters 91: 9097.

Bauer, Philipp C. and Regina T. Riphahn (2009), "Kindergarten enrollment and the intergenerational transmission of education." Discussion paper no. 4466 (Institute for the Study of Labor (IZA), Bonn).

Beaulieu, Nicolas, Duclos Jean-Yves, Fortin Bernard and Manon Rouleau (2005), "Intergenerational reliance on social assistance: Evidence from Canada", Journal of Population Economics 18:539-562.

Becker, Gary S. and Nigel Tomes (1979), “An equilibrium theory of the distribution of income and intergenerational mobility”, Journal of Political Economy 87:1153-189.

Behrman Jere R., Alejandro Gaviria, Miguel Székely, Nancy Birdsall, Sebastián Galiani (2001), "Intergenerational mobility in Latin America," Economía 2: 1-44. 
Behrman, Jere R. and Mark Rosenzweig (2004), "Returns to birthweight", Review of Economics and Statistics 86: 586-601.

Behrman, Jere R. and Mark R. Rosenzweig (2002), “Does increasing women's schooling raise the schooling of the next generation?" American Economic Review 92:323-334.

Behrman, Jere R., Paul Taubman, and Terence Wales (1977), "Controlling for and Measuring the Effects of Genetics and Family Environment in Equations for Schooling and Labor Market Success." In Kinometrics: Determinants of Socioeconomic Success within and between Families, edited by Paul Taubman. Amsterdam: North-Holland.

Bennedsen, Morton, Kasper M. Nielsen, Francisco Pérez-González, and Daniel Wolfenzon (2007), "Inside the family firm: The role of families in succession decisions and performance", Quarterly Journal of Economics 122:647-691.

Bhalotra, Sonia and Samantha Rawlings (2009), "Gradients of the Intergenerational Transmission of Health in Developing Countries" Unpublished Working Paper.

Bhattacharya, Debopam and Bhashkar Mazumder (2008), "Nonparametric analysis of intergenerational income mobility with application to the United States", (Forthcoming Journal of Econometrics).

Bingley, Paul, Kaare Christensen and Vibeke M. Jensen (2009), "Parental schooling and child development: Learning from twin parents", Working paper no. 07:2009 (SFI).

Björklund, Anders and Laura Chadwick (2003), "Intergenerational income mobility in permanent and separated families", Economic Letters 80: 239-46.

Björklund, Anders and Markus Jäntti (2009), "Intergenerational income mobility and the role of family background", in: Wiemer Salverda, Brian Nolan, and Tim Smeeding, eds., Handbook of Economic Inequality (Oxford: Oxford University Press).

Björklund, Anders, Jesper Roine and Daniel Waldenström (2008), “Intergenerational top income mobility in Sweden: A combination of equal opportunity and capitalistic dynasties", Discussion paper no. 3801 (Institute for the Study of Labor (IZA)).

Björklund Anders, Karin Hederos Eriksson, and Markus Jäntti (2010), "IQ and family background: Are associations strong or weak?" The B.E. Journal of Economic Analysis and Policy (Contributions) 10(1).

Björklund, Anders, Markus Jäntti, and Gary Solon (2007), "Nature and nurture in the intergenerational transmission of socioeconomic status: Evidence from Swedish children and their biological and rearing parents", The B.E. Journal of Economic Analysis and Policy 7, Article 4.

Björklund, Anders, Markus Jäntti, and Gary Solon (2005), “Influences of nature and 
nurture on earnings variation: A report on a study of various sibling types in Sweden", in: Samuel Bowles, Herbert Gintis, and Melissa Osborne Groves, eds., Unequal Chances: Family Background and Economic Success (Princeton: Princeton University Press) pp. 145-164.

Björklund, Anders, Markus Jäntti and Matthew J. Lindquist (2009), "Family background and income during the rise of the welfare state: Brother correlations in income for Swedish men born 1932-1968", Journal of Public Economics 93: 671-680.

Björklund, Anders, Mikael Lindahl, and Erik Plug (2006), "The origins of intergenerational associations: Lessons from Swedish adoption data." Quarterly Journal of Economics 121: 999-1028.

Björklund, Anders, Tor Eriksson, Markus Jäntti, Oddbjorn Raaum and Eva Österbacka (2002). "Brother correlations in earnings in Denmark, Finland, Norway and Sweden compared to the United States," Journal of Population Economics 15: 757-772.

Black, Sandra, Paul Devereux, and Kjell Salvanes (2009), "Like father, like son? A note on the intergenerational transmission of IQ scores", Economics Letters 105: 138-140.

Black, Sandra E., Paul J. Devereux, and Kjells G. Salvanes (2007), "From the cradle to the labor market? The effect of birth weight on adult outcomes", Quarterly Journal of Economics 122: 409-439.

Black, Sandra E., Paul J. Devereux and Kjell G. Salvanes (2005), “Why the apple doesn't fall far: Understanding intergenerational transmission of human capital", American Economic Review 95: 437-449.

Blanden, Jo (2009), "How much can we learn from international comparisons of intergenerational mobility?" Paper no. CEEDP0111 (Centre for the Economics of Education, LSE).

Blanden, Jo, Alissa Goodman, Paul Gregg and Stephen Machin (2004), "Changes in intergenerational mobility in Britain," in M. Corak (ed.) Generational Income Mobility in North America and Europe (Cambridge University Press).

Blanden Jo and Stephen Machin (2004), "Educational inequality and the expansion of UK higher education", Scottish Journal of Political Economy 51: 230-249.

Blanden Jo, Paul Gregg and Lindsey Macmillan (2007), “Accounting for intergenerational persistence”, Economic Journal 117: C43-C60.

Böhlmark, Anders and Matthew J. Lindquist (2006), "Life-Cycle Variations in the association between current and lifetime income: replication and extension for Sweden", Journal of Labor Economics 24: 879-96. 
Bound, John and Gary Solon (1999), "Double trouble: On the value of twins-based estimation of the return to schooling", Economics of Education Review 18: 169-182.

Bouchard Jr. Thomas and Matthew McGue (1981), "Familial studies of intelligence: A review", Science 212: 1055-1059.

Bowles, Samuel and Herbert Gintis (2002), "The inheritance of inequality”, Journal of Economic Perspectives 16:3-30.

Bratberg, Espen, Oivind A. Nilsen and Kjell Vaage (2008), "Job losses and child outcomes", Labour Economics 15: 591-603.

Bratberg, Espen, Oivind A. Nielsen, and Kjell Vaage (2007), "Trends in intergenerational mobility across offspring's earnings distribution in Norway", Industrial Relations 46: 112- 29.

Bratberg, Espen, Oivind A. Nielsen and Kjell Vaage (2005), "Intergenerational earnings mobility in Norway: levels and trends", Scandinavian Journal of Economics 107: 419-35.

Bratsberg, Bernt, Knut Røed, Oddbjorn Raaum, Robin. A. Naylor, Jäntti Markus, Eriksson and Eva Österbacka (2007), "Nonlinearities in intergenerational earnings mobility: consequences for cross-country comparisons", Economic Journal 117: C72-92.

Brenner, Jan (2010), "Life-cycle variations in the association between current and lifetime earnings: Evidence for German natives and guest workers", Labour Economics 17: 392-406.

Carmichael, Fiona (2000), "Intergenerational mobility and occupational status in Britain”, Applied Economics Letters 7:391-6.

Carneiro, Pedro, Costas Meghir, and Matthias Parey (2007), "Maternal education, home environments and the development of children and adolescents," Discussion paper no. 3072 (Institute for the Study of Labor (IZA), Bonn).

Chadwick Laura and Gary Solon (2002), "Intergenerational income mobility among daughters", American Economic Review 92: 335-44.

Charles Kerwin K. and Erik Hurst Charles (2003), "The correlation of wealth across generations", The Journal of Political Economy 111: 1155-1182.

Checchi, Daniele, Carlo Fiorio, and Marco Leonardi (2008), "Intergenerational persistence in educational attainment in Italy", Discussion paper no. 3622 (Institute for the Study of Labor (IZA), Bonn).

Chevalier, Arnaud (2004), "Parental Education and Child's Education: A natural experiment”, Discussion paper no. 1153 (Institute for the Study of Labor (IZA), Bonn). 
Chevalier, Arnaud, Colm Harmon, Vincent O'Sullivan, and Ian Walker (2005), “The Impact of parental income and education on the schooling of their children", Discussion paper no. 1496 (Institute for the Study of Labor (IZA), Bonn).

Chevalier, Arnaud, Kevin Denny, and Dorren McMahon (2009), "A Multi-country study of inter-generational educational mobility" in: Peter Dolton, Rita Asplundh and Erling Barth, eds., Education and inequality Across Europe (Edward Elgar, London).

Coneus, Katja and Katharina C. Spieß (2008), "The Intergenerational transmission of health in early childhood", SOEP papers 126, (DIW Berlin, The German Socio-Economic Panel).

Corak, Miles (2006), "Do poor children become poor adults? Lessons from a cross country comparison of generational earnings mobility." in: John Creedy and Guyonne Kalb ed., Research on Economic Inequality, Vol. XIII (Amsterdam) pp. 143-188.

Corak, Miles and Andrew Heisz (1999), "The intergenerational earnings and income mobility of Canadian Men", Journal of Human Resources. 34:504-533.

Corak, Miles and Patrizio Piraino (2010), "Intergenerational earnings mobility and the inheritance of employers", Unpublished.

Couch, Kenneth A. and Dean R. Lillard (2004), "Nonlinear patterns of intergenerational mobility in Germany and the United States" in: (M. Corak, ed.), Generational income mobility in North America and Europe (Cambridge University Press: Cambridge) pp. 190-206.

Currie, Janet and Enrico Moretti (2007), "Biology as destiny? Short and long-run determinants of intergenerational transmission of birth weight", Journal of Labor Economics, 25:231-264.

Currie, Janet and Enrico Moretti (2003), "Mother's education and the intergenerational transmission of human capital: Evidence from college openings", Quarterly Journal of Economics, 118: 1495-1532.

Currie, Janet and Rosemary Hyson (1999) "Is the impact of health shocks cushioned by socioeconomic status? The case of low birthweight", American Economic Review 89: $245-250$.

Dahl, Gordon B. and Lance Lochner (2005), "The impact of family income on child achievement", Working paper no. 11279 (NBER, Cambridge, MA).

Davies, James, Jie Zhang, and Jinli Zeng (2005), "Intergenerational mobility under private vs. public education", Scandinavian Journal of Economics 107: 399-417. 
Dickens, William and James R. Flynn (2001), "Heritability estimates versus large environmental effects the IQ paradox resolved", Psychological Review 108: 346-369.

Di Pietro, Giorgio and Peter Urwin (2003), "Intergenerational mobility and occupational status in Italy", Applied Economics Letters 10:793-7.

Dohmen Thomas J., Armin Falk, David Huffman and Uwe Sunde (2008), "The intergenerational transmission of risk and trust attitudes", Working paper no. 2307 (CESifo Group, Munich).

Doyle, Orla, Colm Harmon and Ian Walker (2007), "The impact of parental income and education on child health: Further evidence for England", Working paper no. 788 (University of Warwick, England).

Dunn, Thomas and Douglas Holtz-Eakin (2000), "Financial capital, human capital and the transition to self-employment: Evidence from intergenerational Links", Journal of Labor Economics 18: 282-305.

Eriksson, Tor, Bernt Bratsberg and Oddbjorn Raaum (2005), "Earnings persistence across generations: Transmission through health?” Memorandum 35/2005 (University of Oslo, Norway).

Ermish, John and Marco Francesconi (2002), "Intergenerational mobility in Britain: New evidence from BHPS", in: Miles Corak ed., Generational income mobility in North America and Europe (Cambridge University Press: Cambridge).

Ermisch, John, Marco Francesconi and Thomas Siedler (2006), "Intergenerational mobility and marital Sorting”, Economic Journal 116: 659-679.

Fernandez, Raquel, Alessandra Fogli and Claudia Olivetti (2004), "Mothers and sons: Preference formation and female labor force dynamics", Quarterly Journal of Economics 119: 1249-1299.

Ferrie Joseph P. (2005) "History lessons: The end of American exceptionalism? Mobility in the United States since 1850", The Journal of Economic Perspectives 19: 199-215.

Gaviria, Alejandro (2002), "Intergenerational mobility, sibling inequality and borrowing constraints", Economics of Education Review 2: 331-340.

Goldberger, Arthur S (1979), "Heritability", Economica 46(184): 327-47.

Grawe, Nathan D. (2006), "The extent of lifecycle bias in estimates of intergenerational earnings persistence", Labour Economics 13: 551-570.

Grawe, Nathan D. (2004), "Reconsidering the use of nonlinearities in intergenerational earnings mobility as a test for credit constraints", Journal of Human Resources 39: 813827. 
Grawe, Nathan D. and Casey Mulligan (2002), "Economic interpretations of intergenerational correlations" Journal of Economic Perspectives. 6: 45-58.

Griliches, Zvi (1979), "Sibling Models and Data in Economics: Beginnings of a Survey," Journal of Political Economy, University of Chicago Press, vol. 87(5), pages S37-64, October.

Gronqvist, Erik, Bjorn Ockert, and Jonas Vlachos (2009), “The Intergenerational transmission of cognitive and non-cognitive abilities." Mimeo.

Groves, Melissa O. (2005), "Personality and the intergenerational transmission of economic status" in: Samuel Bowles, Herbert Gintis, and Melissa O. Groves, eds., Unequal chances: Family background and economic success (Princeton: Princeton University Press) pp. 145-164.

Güell, Maia, Sevi Rodríguez-Mora and Chris Telmer (2007), "Intergenerational mobility and the informative content of surnames", Discussion paper no. 6316 (C.E.P.R., London).

Guryan, Jonathan, Erik Hurst, and Melissa Kearney (2008), "Parental Education and Parental Time with Children," Journal of Economic Perspectives 22(3), 23-46.

Haider, Steven J. and Gary Solon (2006), "Life-cycle variation in the association between current and lifetime earnings", American Economic Review 96:1308-1320.

Han, Song and Casey Mulligan (2001), "Human capital, heterogeneity, and estimated degrees of intergenerational mobility”, Economic Journal 111: 207-243.

Harding, David J., Christopher Jencks, Leonard M. Lopoo, and Susan E. Mayer (2005), "The changing effect of family background on the incomes of American adults" in: Bowles, Gintis, and Groves, eds., Unequal chances: Family background and economic success (Russell Sage Foundation: New York).

Heineck, Guido and Regina T. Riphahn (2007), "Intergenerational transmission of educational attainment in Germany: The last five decades", Discussion paper no. 2985 (Institute for the Study of Labor (IZA), Bonn).

Hellerstein, Judith and Melinda Morrill (2008) "Dads and daughters: The changing impact of fathers on women's occupational choices", Mimeo.

Hertz, Tom, Tamara Jayasundera, Patrizio Piraino, Sibel Selcuk, Nicole Smith and Alina Verashchagina (2007), "The inheritance of educational inequality: International comparisons and fifty-year trends", The B.E. Journal of Economic Analysis \& Policy 7, Article 10.

Hirvonen, Lalaina (2008), “Intergenerational earnings mobility among daughters and 
sons: Evidence from Sweden and a comparison with the United States", The American journal of economics and sociology 67(5): 777-826.

Holmlund, Helena. (2008), "Intergenerational Mobility and Assortative mating: Effects of an educational reform", Discussion paper 0091 (Centre for Economics of Education, LSE).

Holmlund, Helena, Mikael Lindahl, and Erik Plug (2008) "The Causal Effect of Parent's Schooling on Children's Schooling: A Comparison of Estimation Methods" (with Mikael Lindahl and Erik Plug), IZA Discussion Paper No. 3630, August 2008.

Ichino, Andrea, Loukas Karabarbounis, Enrico Moretti (2009), "The political economy of intergenerational income mobility", Discussion paper no. 4767 (Institute for the Study of Labor (IZA), Bonn).

Jäntti, Markus, Bernt Bratsberg, Knut Røed, Oddbjørn Raaum, Robin Naylor, Österbacka, Eva, Björklund Anders and Tor Eriksson (2006), "American exceptionalism in a new Light: A comparison of intergenerational earnings mobility in the Nordic countries, the United Kingdom and the United States," Discussion paper no. 1938 (Institute for the Study of Labor (IZA), Bonn).

Jenkins, Stephen (1987), "Snapshots versus movies: Lifecycle biases and the estimation of intergenerational earnings inheritance", European Economic Review 31:1149-1158.

Kramarz, Francis and Oskar N. Skans (2007), "With a little help from my... parents? Family networks and youth labor market entry", CREST, mimeo.

Lee Chul-In and Gary Solon (2009), "Trends in intergenerational income mobility", Review of Economics and Statistics 91: 766-772.

Lefranc, Arnaud and Alain Trannoy (2005), "Intergenerational earnings mobility in France: Is France more mobile than the US?" Annales d'Economie et de Statistique 78: $57-77$.

Leigh, Andrew (2007), "Intergenerational mobility in Australia”, B.E. Journal of Economic Analysis and Policy 7, Article 6.

Levine, Phillip B. and David J. Zimmerman (1996), "The Intergenerational Correlation in AFDC Participation: Welfare Trap or Poverty Trap?" IRP Discussion Paper No. 110096.

Lindeboom, Maarten, Ana Llena Nozal, and Bas van der Klaauw (2009), "Parental education and child health: Evidence from a schooling reform", Journal of Health Economics 28: 109-131.

Liu, Haoming and Jinli Zeng (2009), "Genetic ability and intergenerational earnings mobility”, Journal of Population Economics 22:75-95. 
Lizzeri, Alessandro and Marciano Siniscalchi (2008) "Parental guidance and supervised learning”, Quarterly Journal of Economics 123:1161-1195.

Loken, Katrine V. (2010), "Family income and children's education: Using the Norwegian oil boom as a natural experiment" Labour Economics 17: 118-129.

Loureiro, Maria L., Sanz-de-Galdeano Anna and Vuri Daniela (2006): "Smoking habits: Like father, like son, like mother, like daughter", Discussion paper no. 2279 (Institute for the Study of Labor (IZA), Bonn).

Machin, Steven (2007), "Education expansion and intergenerational mobility in Britain", in: Ludger Woessman and Paul Peterson, eds., Schools and the equal opportunity problem, MIT Press.

Magnuson, Katherine. (2007). Maternal education and children's academic achievement during middle childhood. Developmental Psychology, 43, 1497-1512.

Maurin, Eric and Sandra McNally (2008), "Vive la revolution! Long-term education Returns of 1968 to the angry students", Journal of Labor Economics 26: 1-33.

Mayer, Susan E., Greg Duncan and Ariel Kalil (2004), "Like mother, like daughter? SES and the intergenerational correlation of traits, behaviors and attitudes", Working paper no. 0415 (Harris School of Public Policy Studies, University of Chicago).

Mayer Susan E. and Leonard M. Lopoo (2008), "Government spending and intergenerational mobility", Journal of Public Economics 92: 139-158.

Mazumder, Bhashkar (2008), "Sibling similarities and economic inequality in the US", Journal of Population Economics, 21: 685-701.

Mazumder, Bhashkar (2005), "Fortunate sons: New estimates of intergenerational mobility in the U.S. using social security earnings data", Review of Economics and Statistics 87:235-255.

McCrary, Justin, and Heather Royer (2006), "The effect of female education on fertility and infant health: Evidence from school entry policies using exact date of birth", Working paper no.12329 (NBER, Cambridge, MA).

Meghir Costas and Marten Palme (2005), "Educational reform, ability and family background", American Economic Review 95: 414-424.

Mitnik, Oscar A. (2008), "Intergenerational Transmission of Welfare Dependency: The Effects of Length of Exposure.” Mimeo, March 2.

Mocetti, Sauro (2007), "Intergenerational earnings mobility in Italy", The B.E. Journal of Economic Analysis and Policy 7, Article 5. 
Morris Pamela, Greg J. Duncan and Christopher Rodrigues (2004), "Does money really matter? Estimating impacts of family income on children's achievement with data from random-assignment experiments" Unpublished.

Mulligan, Casey B (1997), Parental priorities and economic inequality (Chicago: University of Chicago Press).

Nicoletti, Cheti and John Ermisch (2007), "Intergenerational earnings mobility: Changes across cohorts in Britain", The B.E. Journal of Economic Analysis and Policy 7, Article 9.

Nilsen, Oivind A., Kjell Vaage, Arild Arkvik and Karl Jacobsen (2008), "Estimates of intergenerational elasticities based on lifetime earnings", Discussion paper no. 3709 (Institute for the Study of Labor (IZA), Bonn).

O’Neill, Donal and Olive Sweetman and Dirk Van de gaer (2007), "The effects of measurement error and omitted variables when using transition matrices to measure intergenerational mobility", Journal of Economic Inequality 5:159-178.

Oreopoulos, Philip (2003), "The long-run consequences of growing up in a poor neighbourhood", Quarterly Journal of Economics 118:1533-1575.

Oreopoulos, Philip, Marianne E. Page and Anne H. Stevens (2008), “The intergenerational effects of worker displacement", Journal of Labor Economics, 26: 455483.

Oreopoulos, Philip, Marianne E. Page and Anne H. Stevens (2006), "The intergenerational effects of compulsory schooling", Journal of Labor Economics 24: 729760 .

Österbacka, Eva (2001), "Family background and economic status in Finland", Scandinavian Journal of Economics 103: 467-484.

Österberg, Torun (2000), "Intergenerational income mobility in Sweden: What do taxdata show?" Review of Income and Wealth 46: 421-36.

Page, Marianne E. (2009), “Fathers' education and children's human capital: Evidence from the world war II G.I. Bill”, Mimeo.

Page, Marianne E (2004), "New evidence on intergenerational correlations in welfare participation", in: Miles Corak, ed., Generational income mobility in North America and Europe (Cambridge University Press, Cambridge).

Page, Marianne E. and Gary Solon (2003a), "Correlations between brothers and neighboring boys in their adult earnings: The importance of being urban", Journal of 
Labor Economics 21: 831-855.

Page, Marianne E. and Gary Solon (2003b), "Correlations between sisters and neighboring girls in their subsequent income as adults", Journal of Applied Econometrics 18: 545-562.

Pekkala, Sari and Robert E.B. Lucas (2007), "Differences across cohorts in Finnish intergenerational income mobility", Industrial Relations 46: 81-111.

Pekkarinen, Tuomas, Roope Uusitalo and Sari Kerr (2009), "School tracking and intergenerational income mobility: Evidence from the Finnish comprehensive school reform", Journal of Public Economics 93: 965-973.

Pepper, John V. (2000), “The intergenerational transmission of welfare receipt: A nonparametric bounds analysis", Review of Economics and Statistics 82: 472-488.

Pérez-González, Francisco (2006), "Inherited control and firm performance”, American Economic Review 96:1559-1588.

Piraino, Patrizio (2007), "Comparable estimates of intergenerational income mobility in Italy”, The B.E. Journal of Economic Analysis and Policy 7, Article 1.

Plug, Erik (2004), “Estimating the effect of mother's schooling on children's schooling using a sample of adoptees", American Economic Review 94: 358-368.

Plug, Erik and Wim Vijverberg (2005), "Does family income matter for schooling outcomes? Using adoptees as a natural experiment", Economic Journal 115: 879-906.

Pronzato, Chiara (2009), “An examination of paternal and maternal intergenerational transmission of schooling", CHILD working paper no. wp20_09 (CHILD - Centre for Household, Income, Labour and Demographic economics, Italy).

Raaum, Oddbjørn, Bernt Bratsberg, Knut Røed, Eva Österbacka, Tor Eriksson, Markus Jäntti and Robin A. Naylor (2007), "Marital sorting, household labor supply and intergenerational earnings mobility across countries", The B.E. Journal of Economic Analysis and Policy, Article 7.

Raaum, Oddbjørn, Kjell G. Salvanes and Erik O. Sorensen (2006), “The neighborhood is not what it used to be", Economic Journal, 116: 200-22.

Rege, Mari, Kjetil Telle and Mark Votruba (2007), "Parental job loss and children's school performance", Discussion paper no. 517 (Research Department, Statistics Norway).

Reville, Robert T (1995), "Intertemporal and life cycle variation in measured intergenerational earnings mobility”, RAND working paper (Santa Monica, CA: RAND 
Corporation).

Royer, Heather (2009), "Separated at girth: Estimating the long-run and intergenerational Effects of Birthweight using Twins", American Economic Journal - Applied Economics.

Sacerdote, Bruce (2008), "Nature and nurture effects on children's outcomes: What have we have learned from studies of twins and adoptees?" forthcoming in the Handbook of Social Economics (Amsterdam: North Holland).

Sacerdote, Bruce (2007), "How large are the effects from changes in family environment? A study of Korean American adoptees", Quarterly Journal of Economics 122: 119-157.

Sacerdote, Bruce (2002), "The nature and nurture of economic outcomes", American Economic Review 92: 344-48.

Sacerdote, Bruce (2000), "The nature and nurture of economic outcomes", Working paper no. 7949 (NBER, Cambridge, MA).

Shea, John (2000), “Does Parents’ Money Matter?”, Journal of Public Economics 77: 155-84.

Solon, Gary (2004), “A model of intergenerational mobility variation over time and place”, in: Miles Corak, ed., Generational income mobility in North America and Europe (Cambridge University Press: Cambridge) pp. 38-47.

Solon, Gary (2002), "Cross-country Differences in intergenerational earnings mobility", Journal of Economic Perspectives 16: 59-66.

Solon, Gary (1999), "Intergenerational mobility in the labor market", in: Orley Ashenfelter and David Card, eds., Handbook of labor economics, Vol. III (Amsterdam: North-Holland) pp. 1761-1800.

Solon, Gary (1992) "Intergenerational income mobility in the United States", American Economic Review 82: 393-408.

Solon, Gary, Marianne Page, and Greg Duncan (2000), “Correlations between Neighboring Children in Their Subsequent Educational Attainment”, Review of Economics and Statistics, 82/3: 383-92.

Vogel, Thorsten (2008), "Reassessing intergenerational mobility in Germany and the United States: the impact of differences in lifecycle earnings patterns", Discussion paper no. SFB649DP2006-055 (Sonderforschungsbereich 649, Berlin).

Waldkirch, Andreas, Serena Ng and Donald Cox (2004), "Intergenerational linkages in consumption behaviour” Journal of Human Resources 39: 355-381. 
Wilhelm, Mark O. Eleanor Brown, Patrick M. Rooney and Richard S. Steinberg (2008), "The intergenerational transmission of generosity", Journal of Public Economics 92: 2146-2156.

Zimmerman, David J. (1992), "Regression toward mediocrity in economic stature", American Economic Review 82: 409-429. 